\title{
Development and evaluation of an ozone deposition scheme for coupling to a terrestrial biosphere model
}

\author{
Martina Franz ${ }^{1,2}$, David Simpson ${ }^{4,5}$, Almut Arneth ${ }^{6}$, and Sönke Zaehle ${ }^{1,3}$ \\ ${ }^{1}$ Biogeochemical Integration Department, Max Planck Institute for Biogeochemistry, Jena, Germany \\ ${ }^{2}$ International Max Planck Research School (IMPRS) for Global Biogeochemical Cycles, Jena, Germany \\ ${ }^{3}$ Michael Stifel Center Jena for Data-driven and Simulation Science, Jena, Germany \\ ${ }^{4}$ EMEP MSC-W, Norwegian Meteorological Institute, Oslo, Norway \\ ${ }^{5}$ Department of Earth \& Space Sciences, Chalmers University of Technology, Gothenburg, Sweden \\ ${ }^{6}$ Karlsruhe Institute of Technology (KIT), Department of Atmospheric Environmental Research (IMK-IFU), \\ Garmisch-Partenkirchen, Germany
}

Correspondence to: Martina Franz (mfranz@bgc-jena.mpg.de)

Received: 18 July 2016 - Published in Biogeosciences Discuss.: 28 July 2016

Revised: 11 November 2016 - Accepted: 12 December 2016 - Published: 6 January 2017

\begin{abstract}
Ozone $\left(\mathrm{O}_{3}\right)$ is a toxic air pollutant that can damage plant leaves and substantially affect the plant's gross primary production (GPP) and health. Realistic estimates of the effects of tropospheric anthropogenic $\mathrm{O}_{3}$ on GPP are thus potentially important to assess the strength of the terrestrial biosphere as a carbon sink. To better understand the impact of ozone damage on the terrestrial carbon cycle, we developed a module to estimate $\mathrm{O}_{3}$ uptake and damage of plants for a state-of-the-art global terrestrial biosphere model called OCN. Our approach accounts for ozone damage by calculating (a) $\mathrm{O}_{3}$ transport from $45 \mathrm{~m}$ height to leaf level, (b) $\mathrm{O}_{3}$ flux into the leaf, and (c) ozone damage of photosynthesis as a function of the accumulated $\mathrm{O}_{3}$ uptake over the lifetime of a leaf.

A comparison of modelled canopy conductance, GPP, and latent heat to FLUXNET data across European forest and grassland sites shows a general good performance of OCN including ozone damage. This comparison provides a good baseline on top of which ozone damage can be evaluated. In comparison to literature values, we demonstrate that the new model version produces realistic $\mathrm{O}_{3}$ surface resistances, $\mathrm{O}_{3}$ deposition velocities, and stomatal to total $\mathrm{O}_{3}$ flux ratios. A sensitivity study reveals that key metrics of the air-to-leaf $\mathrm{O}_{3}$ transport and $\mathrm{O}_{3}$ deposition, in particular the stomatal $\mathrm{O}_{3}$ uptake, are reasonably robust against uncertainty in the underlying parameterisation of the deposition scheme. Nevertheless, correctly estimating canopy conductance plays a
\end{abstract}

pivotal role in the estimate of cumulative $\mathrm{O}_{3}$ uptake. We further find that accounting for stomatal and non-stomatal uptake processes substantially affects simulated plant $\mathrm{O}_{3}$ uptake and accumulation, because aerodynamic resistance and non-stomatal $\mathrm{O}_{3}$ destruction reduce the predicted leaf-level $\mathrm{O}_{3}$ concentrations. Ozone impacts on GPP and transpiration in a Europe-wide simulation indicate that tropospheric $\mathrm{O}_{3}$ impacts the regional carbon and water cycling less than expected from previous studies. This study presents a first step towards the integration of atmospheric chemistry and ecosystem dynamics modelling, which would allow for assessing the wider feedbacks between vegetation ozone uptake and tropospheric ozone burden.

\section{Introduction}

Tropospheric ozone $\left(\mathrm{O}_{3}\right)$ is a highly reactive and toxic gas. It enters the plants mainly through the stomata of the leaf, where it forms reactive oxygen species (ROSs), which have the potential to damage the leaf. While leaves possess physiological pathways to produce compounds like ascorbate and polyamines, which help to neutralise the oxidising power of ROSs (Kronfuß et al., 1998; Kangasjärvi et al., 1994; Tausz et al., 2007), ozone injury may occur when the leaf's antioxidant system becomes overwhelmed (Wieser and Matyssek, 2007). 
In western Europe, tropospheric $\mathrm{O}_{3}$ levels increased approximately by a factor 2 to 5 from pre-industrial values to the 1990s (Cooper et al., 2014; Marenco et al., 1994; Staehelin et al., 1994) (although the low values at the start of this period are very uncertain) and approximately doubled between 1950 and 1990s in the Northern Hemisphere (Parrish et al., 2012; Cooper et al., 2014). The major causes for this increased $\mathrm{O}_{3}$ formation are the increased emission of $\mathrm{O}_{3}$ precursor trace gases such as $\mathrm{NO}_{x}$ and $\mathrm{CO}$, primarily from combustion sources, non-methane volatile organic compounds from anthropogenic sources (combustion, solvents), and methane emissions from agriculture and industry (Fusco and Logan, 2003; Vingarzan, 2004). For instance, in western Europe, $\mathrm{NO}_{x}$ emissions rose by a factor of 4.5 between 1955 and 1985 (Staehelin et al., 1994). In addition, downward transport of $\mathrm{O}_{3}$ from the stratosphere to the troposphere (Vingarzan, 2004; Young et al., 2013) and intercontinental transport (Vingarzan, 2004; Jenkin, 2008; Fiore et al., 2009) can increase local and regional $\mathrm{O}_{3}$ concentrations.

A commonly observed consequence of elevated levels of $\mathrm{O}_{3}$ exposure is a decline in net photosynthesis (Morgan et al., 2003; Wittig et al., 2007), which may result from the damage of the photosynthetic apparatus or increased respiration due to the production of defence compounds and investments in injury repair (Wieser and Matyssek, 2007; Ainsworth et al., 2012). The reduction in net photosynthesis results in reduced growth and hence a reduced leaf area and plant biomass (Morgan et al., 2003; Lombardozzi et al., 2013; Wittig et al., 2009). The tight coupling between photosynthesis and stomatal conductance further affects canopy conductance, and thereby transpiration rates (Morgan et al., 2003; Wittig et al., 2009; Lombardozzi et al., 2013), likely affecting the ecosystem water balance.

Due to its phytotoxic effect, elevated $\mathrm{O}_{3}$ levels as a consequence of anthropogenic air pollution may affect the land carbon cycle and potentially reduce the net land carbon uptake capacity (Sitch et al., 2007; Arneth et al., 2010; Simpson et al., 2014a), which currently corresponds to about a quarter of the anthropogenic fossil fuel emissions as a result of a sustained imbalance between photosynthetic carbon uptake and carbon loss through respiration and disturbance processes (Le Quéré et al., 2015). However, the extent to which $\mathrm{O}_{3}$ affects plant health regionally and thereby alters terrestrial biogeochemistry and the terrestrial water balance is still subject of large uncertainty (Simpson et al., 2014a).

A number of $\mathrm{O}_{3}$ exposure indices have been proposed to assess the potential detrimental effect of tropospheric $\mathrm{O}_{3}$ on the plants (LRTAP Convention, 2010; Mills et al., 2011b). In Europe, the standard method of these indices is the concentration-based AOTX (ppb h) (accumulated $\mathrm{O}_{3}$ concentration over a threshold of $X \mathrm{ppb}$ ), which relates the freeair $\mathrm{O}_{3}$ concentration to observed plant damage. Models assessing ozone damage to gross or net primary production based on AOTX have been used for many years and indicate that substantial reduction in plant growth and carbon sequestration occurs globally and may reach reductions of more than $40 \%$ at $\mathrm{O}_{3}$ hotspots (Felzer et al., 2004, 2005; Ren et al., 2011; Anav et al., 2011).

A significant caveat of concentration-based assessments of ozone toxicity effects is that species differ vastly in their canopy conductance as well as regional provenances of species. Stomatal control of the leaf gas exchange regulates photosynthesis and varies, inter alia, with plant-specific photosynthetic capacity and intrinsic water-use efficiency of photosynthesis; phenology; and environmental factors such as incident light, atmospheric vapour pressure deficit (VPD), and air temperature. The consequent differences in stomatal conductance implies that the actual $\mathrm{O}_{3}$ dose, and thus the level of ozone-related damage, differs between species exposed to similar atmospheric $\mathrm{O}_{3}$ concentrations (Wieser and Havranek, 1995). The $\mathrm{O}_{3}$ dose, which is the integral of the instantaneous $\mathrm{O}_{3}$ stomatal flux over a given period of time, has been observed to strongly correlate with the amount of injury of a plant suggesting that plants with higher stomatal conductance are subject to higher doses and hence more susceptible to injury (Reich, 1987; Wittig et al., 2009).

Accounting for the $\mathrm{O}_{3}$ dose rather than the $\mathrm{O}_{3}$ exposure in assessments of ozone damage results in diverging regional patterns of ozone damage, as regions with the highest exposure $\left(\mathrm{O}_{3}\right.$ concentrations $)$ do not always coincide with regions of high uptake (Emberson et al., 2000; Mills et al., 2011a; Simpson et al., 2007). Regions with low AOT40 (AOTX above a threshold of $40 \mathrm{ppb}$ ) values might show moderate to high values of $\mathrm{O}_{3}$ uptake because the flux approach accounts for climatic conditions that enable high stomatal conductances and hence high values of $\mathrm{O}_{3}$ uptake (Mills et al., 2011a). Observed ozone damage in the field seems to be better correlated with flux-based risk assessment compared to concentration-based methods (Mills et al., 2011a). Following this the LRTAP Convention recommends flux-based methods as the preferred tool for risk assessment (LRTAP Convention, 2010).

When calculating the $\mathrm{O}_{3}$ uptake into the plants, it is important to consider that stomatal uptake is not the only surface sink of $\mathrm{O}_{3} \cdot \mathrm{O}_{3}$ destruction also occurs at non-stomatal surfaces such as the leaves' cuticle and soil surface. The stomatal flux represents approximately half of the total $\mathrm{O}_{3}$ flux to the surface (Gerosa et al., 2004; Fowler et al., 2009; Cieslik, 2004; Simpson et al., 2003). Accounting for this nonstomatal $\mathrm{O}_{3}$ deposition reduces the amount of $\mathrm{O}_{3}$ uptake into the plants by reducing the surface $\mathrm{O}_{3}$ concentration (Tuovinen et al., 2009) and thus has the potential to affect flux-based ozone damage estimates.

A further challenge in estimating plant damage related to $\mathrm{O}_{3}$ uptake is that plants differ in their ability to remove any ROS from the leaf before damage of leaf cellular organs is incurred (Luwe and Heber, 1995). Conceptually, one can describe the capacity as a plant-specific $\mathrm{O}_{3}$ dose with which the antioxidant system of the leaves can cope such that no damage is observed (Musselman et al., 2006). The produc- 
tion of defence compounds increases respiration costs and following this reduces net primary production what may result in reduced growth and biomass (Ainsworth et al., 2012). Ozone damage is only incurred once the $\mathrm{O}_{3}$ flux into the leaf exceeds this dose. A commonly used index to assess fluxbased damage to plants is the PODy (phytotoxic ozone dose, nmol m${ }^{-2} \mathrm{~s}^{-1}$ ), which gives the accumulated $\mathrm{O}_{3}$ flux above a threshold of $Y$ nmol m${ }^{-2} \mathrm{~s}^{-1}$ for all daylight hours and a given time period. Common threshold values for PODy range from 1 to $6 \mathrm{nmol} \mathrm{m}^{-2} \mathrm{~s}^{-1}$ (Pleijel et al., 2007; LRTAP Convention, 2010; Mills et al., 2011b), depending on the specific species sensitivity to $\mathrm{O}_{3}$.

Only a few terrestrial biosphere models have adopted the flux approach to relate $\mathrm{O}_{3}$ exposure to plant damage and thus estimate $\mathrm{O}_{3}$-induced reductions in terrestrial carbon sequestration in a process-based manner. Sitch et al. (2007) developed a version of the JULES model in which stomatal $\mathrm{O}_{3}$ uptake directly affects net primary production (NPP), thereby ignoring the effect of reduced photosynthesis under elevated levels of $\mathrm{O}_{3}$ on water fluxes. Lombardozzi et al. (2015) proposed a revised version of the Community Land Model (CLM), in which $\mathrm{O}_{3}$ imposes fixed reductions to net photosynthesis for two out of three modelled plant types. Atmospheric $\mathrm{O}_{3}$ concentrations and the amount of cumulated $\mathrm{O}_{3}$ uptake directly affect net photosynthesis only for one plant type.

In this paper, we present a new, globally applicable model to calculate $\mathrm{O}_{3}$ uptake and damage in a process-oriented manner, coupled to the terrestrial energy, water, carbon, and nitrogen budget of the OCN terrestrial biosphere model ( $\mathrm{Za}$ ehle and Friend, 2010).

In this model, the canopy $\mathrm{O}_{3}$ abundance is calculated using aerodynamic resistance and surface resistances to soil surface, vegetation surfaces, and stomatal cavities to take account of non-stomatal $\mathrm{O}_{3}$ destruction. Canopy $\mathrm{O}_{3}$ abundance is used to simulate stomatal $\mathrm{O}_{3}$ uptake given instantaneous values of net photosynthesis and stomatal conductance. $\mathrm{O}_{3}$ uptake and its effect on net photosynthesis is then calculated based on an extensive meta-analysis across 28 tree species by Wittig et al. (2007) considering the ability of plants to detoxify a proportion of the $\mathrm{O}_{3}$ dose (Sitch et al., 2007).

We first give a detailed overview of the ozone scheme (Sect. 2.1); evaluate modelled gross primary production (GPP), canopy conductance, latent heat fluxes, and leaf area index (LAI) against data from the FLUXNET database (Baldocchi et al., 2001) to test the ability of the model to simulate observed values of key components affecting calculate $\mathrm{O}_{3}$ uptake (Sect. 3.1); evaluate the simulated $\mathrm{O}_{3}$ metrics against reported values in the literature (Sect. 3.2); provide a sensitivity analysis of critical variables and parameters of the deposition model to evaluate the reliability of simulated values of $\mathrm{O}_{3}$ uptake (Sect. 3.3); give an estimate of the effect of the present-day $\mathrm{O}_{3}$ burden on European GPP and transpiration(Sect. 3.4); and estimate the impact of using the $\mathrm{O}_{3}$ deposition scheme on $\mathrm{O}_{3}$ uptake and cumulated uptake (Sect. 3.5).

\section{Methods}

We developed an ozone deposition and leaf-uptake module for the terrestrial biosphere model OCN (Zaehle and Friend, 2010). OCN is a further development of the land-surface scheme ORCHIDEE (O) (Krinner et al., 2005), and simulates the terrestrial coupled carbon $(\mathrm{C})$, nitrogen $(\mathrm{N})$, and water cycles for 12 plant functional types (PFTs) driven by climate data, atmospheric composition ( $\mathrm{N}$ deposition, as well as atmospheric $\mathrm{CO}_{2}$ and $\mathrm{O}_{3}$ burden), and land-use information (land cover and fertiliser application).

In OCN net photosynthesis is calculated for shaded and sunlit leaves in a multi-layer canopy with up to 20 layers (each with a thickness of up to 0.5 leaf area index) following a modified Farquhar scheme and considering the light profiles of diffuse and direct radiation (Zaehle and Friend, 2010). Photosynthetic capacity depends on leaf nitrogen concentration and leaf area, which are both affected by ecosystem available $\mathrm{N}$. Increases in leaf nitrogen content enable higher net photosynthesis and higher stomatal conductance per unit leaf area. This in turn affects transpiration as well as $\mathrm{O}_{3}$ uptake and ozone damage estimates. Leaf $\mathrm{N}$ is highest in the top canopy and monotonically decreases with increasing canopy depth. Following this, stomatal conductance and $\mathrm{O}_{3}$ uptake is generally highest in the upper canopy and lowest in the bottom of the canopy.

The $\mathrm{O}_{3}$ and $\mathrm{N}$-deposition data used for this study are provided by the EMEP MSC-W (European Monitoring and Evaluation Programme Meteorological Synthesizing Centre - West) chemical transport model (CTM) (Simpson et al., 2012). The $\mathrm{O}_{3}$ flux and deposition modules used in the EMEP model are advanced compared to most CTMs, and have been documented in a number of papers (Emberson et al., 2001; Tuovinen et al., 2004, 2009; Simpson et al., 2007, 2012; Klingberg et al., 2008). The ozone deposition scheme for OCN is adapted from the model used by EMEP MSC-W (Simpson et al., 2012) to fit the land-surface characteristics and process descriptions of the ORCHIDEE model. The leaf-level ozone concentrations computed by EMEP can not directly be used by OCN, since EMEP and OCN differ in a number of properties, as for instance in the number of simulated PFTs, and importantly their ecophysiological process representation. Both models differ in the simulation of various ecosystem processes (e.g. phenology, canopy processes, biogeochemical cycles, and vegetation dynamics, which are more explicitly represented in OCN), which in sum impact stomatal and non-stomatal ozone deposition and through this the leaf-level ozone concentration. A possible further development of the new OCN is the coupling to a CTM to allow for a consistent simulation of tropospheric $\mathrm{O}_{3}$ burden and vegetation $\mathrm{O}_{3}$ uptake. 


\subsection{Ozone module}

The ozone deposition scheme calculates $\mathrm{O}_{3}$ deposition to the leaf surface from the free atmosphere, represented by the $\mathrm{O}_{3}$ concentration at the lowest level of the atmospheric CTM, taken to be at $45 \mathrm{~m}$ above the surface. The total $\mathrm{O}_{3}$ dry deposition flux $\left(F_{\mathrm{g}}\right)$ to the ground surface is calculated as

$F_{\mathrm{g}}=V_{\mathrm{g}} \chi_{\mathrm{atm}}^{\mathrm{O}_{3}}$

where $\chi_{\mathrm{atm}}^{\mathrm{O}_{3}}$ is the $\mathrm{O}_{3}$ concentration at $45 \mathrm{~m}$ and $V_{\mathrm{g}}$ is the deposition velocity at that height. In OCN $V_{\mathrm{g}}$ is taken to be dependent on the aerodynamic resistance $\left(R_{\mathrm{a}}\right)$, canopy-scale quasi-laminar layer resistance $\left(R_{\mathrm{b}}\right)$ and the compound surface resistance $\left(R_{\mathrm{c}}\right)$ to $\mathrm{O}_{3}$ deposition.

$V_{\mathrm{g}}=\frac{1}{R_{\mathrm{a}}+R_{\mathrm{b}}+R_{\mathrm{c}}}$

$R_{\mathrm{b}}$ is calculated from the friction velocity $\left(u_{*}\right)$ as

$R_{\mathrm{b}}=\frac{6}{u_{*}}$.

The $R_{\mathrm{a}}$ between $45 \mathrm{~m}$ height and the canopy is not computed by OCN and is inferred from the logarithmic wind profile (for more details see Appendix A). $R_{\mathrm{c}}$ is calculated as the sum of the parallel resistances to stomatal/canopy $\left(1 / G_{\mathrm{c}}^{\mathrm{O}_{3}}\right)$ and non-stomatal $\mathrm{O}_{3}$ uptake $\left(1 / G_{\mathrm{ns}}\right)$ (Simpson et al., 2012, Eq. 55):

$R_{\mathrm{c}}=\frac{1}{G_{\mathrm{c}}^{\mathrm{O}_{3}}+G_{\mathrm{ns}}}$

The stomatal conductance to $\mathrm{O}_{3} G_{\text {st }}^{\mathrm{O}_{3}}\left(\mathrm{~m} \mathrm{~s}^{-1}\right)$ is computed by OCN (Zaehle and Friend, 2010) as

$G_{\mathrm{st}}^{\mathrm{O}_{3}}=g_{1} \frac{f(\Theta) f\left(q_{\mathrm{air}}\right) f\left(C_{i}\right) f(\text { height }) A_{n, \mathrm{sat}}}{1.51}$,

where $G_{\mathrm{st}}^{\mathrm{O}_{3}}$ is calculated as a function of net photosynthesis at saturating $C_{i}\left(A_{n \text {,sat }}\right)$, where $g_{1}$ is the intrinsic slope between $A_{\mathrm{n}}$ and $G_{\mathrm{st}}$. It further depends on a number of scalars to account for the effect of soil moisture $(f(\Theta))$, water transport limitation with canopy height ( $f$ (height)), and atmospheric drought $\left.\left(f_{(} q_{\text {air }}\right)\right)$, as well as an empirical non-linear sensitivity to the internal leaf $\mathrm{CO}_{2}$ concentration $\left(f\left(C_{i}\right)\right)$, all as described in Friend and Kiang (2005). The factor 1.51 accounts for the different diffusivity of $\mathrm{O}_{3}$ from water vapour (Massman, 1998). The canopy conductance to $\mathrm{O}_{3} G_{\mathrm{c}}^{\mathrm{O}_{3}}$ is calculated by summing the $G_{\text {st }}^{\mathrm{O}_{3}}$ of all canopy layers. To yield reasonable conductance values in OCN compared to FLUXNET data (see Sect. 3.1), the original intrinsic slope between $A_{\mathrm{n}}$ and $G_{\mathrm{c}}$ called $\alpha$ in Friend and Kiang (2005) is adapted such that $g_{1}=0.7 \alpha$.
The non-stomatal conductance $G_{\text {ns }}$ follows the EMEP approach (Simpson et al., 2012, Eq. 60) and represents the $\mathrm{O}_{3}$ fluxes between canopy-air space and surfaces other than the stomatal cavities. The model accounts for $\mathrm{O}_{3}$ destruction on the leaf surface $\left(r_{\text {ext }}\right)$, within-canopy resistance to $\mathrm{O}_{3}$ transport $\left(R_{\mathrm{inc}}\right)$, and ground surface resistance $\left(R_{\mathrm{gs}}\right)$ :

$G_{\mathrm{ns}}=\frac{\mathrm{SAI}}{r_{\mathrm{ext}}}+\frac{1}{R_{\mathrm{inc}}+R_{\mathrm{gs}}}$,

where the surface area index (SAI) is equal to the LAI for herbaceous PFTs (grasses and crops) and SAI $=\mathrm{LAI}+1$ for tree PFTs according to Simpson et al. (2012) in order to account for $\mathrm{O}_{3}$ destruction on branches and stems. Unlike EMEP, we do not apply a day of the growing season constraint for crop exposure to $\mathrm{O}_{3}$, which in $\mathrm{OCN}$ is accounted for by the simulated phenology and seasonality of photosynthesis. The external leaf resistance $\left(r_{\text {ext }}\right)$ per unit surface area is calculated as

$r_{\mathrm{ext}}=r_{\mathrm{ext}, b} F_{T}$

where the base external leaf resistance $\left(r_{\mathrm{ext}, b}\right)$ of $2500 \mathrm{~m} \mathrm{~s}^{-1}$ is scaled by a low-temperature correction factor $F_{T}$ and

$F_{T}=e^{-0.2\left(1+T_{\mathrm{s}}\right)}$,

with $1 \leq F_{T} \leq 2$ and $T_{\mathrm{S}}$ the $2 \mathrm{~m}$ air temperature $\left({ }^{\circ} \mathrm{C}\right.$ Simpson et al., 2012, Eq. 60). For temperatures below $-1{ }^{\circ} \mathrm{C}$ nonstomatal resistances are increased up to two times (Simpson et al., 2012; Zhang et al., 2003). The within-canopy resistance $\left(R_{\text {inc }}\right)$ is calculated as

$R_{\mathrm{inc}}=b \mathrm{SAI} \frac{h}{u_{*}}$,

where $b$ is an empirical constant (set to $14 \mathrm{~s}^{-1}$ ) and $h$ is the canopy height in $\mathrm{m}$. The ground-surface resistance $R_{\mathrm{gs}}$ is calculated as

$R_{\mathrm{gs}}=\frac{1-2 f_{\text {snow }}}{F_{T} \hat{R}_{\mathrm{gs}}}+\frac{2 f_{\text {snow }}}{R_{\text {snow }}}$

(Simpson et al., 2012, Eq. 59). $\hat{R}_{\mathrm{gs}}$ represents base values of $R_{\mathrm{gs}}$ and takes values of $2000 \mathrm{~s} \mathrm{~m}^{-1}$ for bare soil, $200 \mathrm{~s} \mathrm{~m}^{-1}$ for forests and crops, and $1000 \mathrm{~s} \mathrm{~m}^{-1}$ for non-crop grasses (Simpson et al., 2012, Suppl.). As in EMEP, the groundsurface resistance of $\mathrm{O}_{3}$ to snow $\left(R_{\text {snow }}\right)$ is set to a value of $2000 \mathrm{~s} \mathrm{~m}^{-1}$ according to Zhang et al. (2003). $f_{\text {snow }}$ is calculated from the actual snow depth $\left(s_{\mathrm{d}}\right)$ simulated by OCN, and the maximum possible snow depth $\left(s_{\mathrm{d}, \max }\right)$ :

$f_{\text {snow }}=\frac{s_{\mathrm{d}}}{s_{\mathrm{d}, \text { max }}}$

with the constraint of $0 \leq f_{\text {snow }} \leq 0.5$ to prevent negative values in the first fraction of Eq. (10). $s_{\mathrm{d}, \max }$ is taken to be $10 \mathrm{kgm}^{-2}$ (Ducoudré et al., 1993). 
Given these resistances, the canopy $\mathrm{O}_{3}$ concentration $\left(\chi_{\mathrm{c}}^{\mathrm{O}_{3}}, \mathrm{nmolm}^{-3}\right)$ is then calculated based on a constant flux assumption:

$\chi_{\mathrm{c}}^{\mathrm{O}_{3}}=\chi_{\mathrm{atm}}^{\mathrm{O}_{3}}\left(1-\frac{R_{\mathrm{a}}}{R_{\mathrm{a}}+R_{\mathrm{b}}+R_{\mathrm{c}}}\right)$.

$\chi_{\mathrm{c}}^{\mathrm{O}_{3}}$ and the stomatal conductance to $\mathrm{O}_{3}\left(G_{\mathrm{st}}^{\mathrm{O}_{3}}\right.$ in $\left.\mathrm{ms}^{-1}\right)$ are used to calculate the $\mathrm{O}_{3}$ flux into the leaf cavities $\left(F_{\mathrm{st}}\right.$, nmol $\left.\mathrm{m}^{-2} \mathrm{~s}^{-1}\right)$ :

$F_{\mathrm{st}}=\left(\chi_{\mathrm{c}}^{\mathrm{O}_{3}}-\chi_{i}^{\mathrm{O}_{3}}\right) G_{\mathrm{st}}^{\mathrm{O}_{3}}$.

According to Laisk et al. (1989) the leaf internal $\mathrm{O}_{3}$ concentration $\left(\chi_{i}^{\mathrm{O}_{3}}\right)$ is assumed to be zero.

The OCN implementation of deposition and flux described above is a simplification of the deposition system used by EMEP in order to fit the process representation of ORCHIDEE, from which OCN has inherited its biophysical modules. The external leaf resistance is not included in the calculation of $F_{\text {st }}$ (Tuovinen et al., 2007, 2009), which results in an overestimation of stomatal $\mathrm{O}_{3}$ uptake. Further, OCN's calculation of $R_{\mathrm{a}}$ is based upon neutral stability conditions (see Appendix), whereas the EMEP model makes use of rather detailed stability correction factors. However, a series of calculations with the full EMEP model have shown that the uncertainties associated with these simplifications are small, typically $0.5-5 \mathrm{mmol} \mathrm{m}^{-2}$. As base-case values of POD0 are typically ca. $30-50 \mathrm{mmol} \mathrm{m}^{-2}$ in EU regions, these approximations do not seem to be a major cause of error, at least in regions with substantial ozone (and carbon) uptake. The full coupling of OCN to a CTM would be desirable to eliminate this bias and allow for a consistent calculation of tropospheric and surface near $\mathrm{O}_{3}$ burdens.

\subsection{Relating stomatal uptake to leaf damage}

An accumulation of $F_{\text {st }}$ over time gives the accumulated uptake of $\mathrm{O}_{3}$ for a particular canopy layer $\left(\mathrm{CUO}_{1}, \mathrm{mmolm}^{-2}\right)$, or for $l=1$ (top canopy layer) the phytotoxic $\mathrm{O}_{3}$ dose (POD, $\left.\mathrm{mmol} \mathrm{m}^{-2}\right)$ :

$$
\frac{\mathrm{dCUO}_{1}}{\mathrm{~d} t}=\left(1-f_{\text {new }}\right) \mathrm{CUO}_{1}+c F_{\mathrm{st}, 1},
$$

where $c=10^{-6}$ converts from nmol to mmol and the integration time step is $1800 \mathrm{~s}$.

The phenology of leaves is accounted for by assuming that emerging leaves are undamaged and by reducing the $\mathrm{CUO}_{1}$ by the fraction of newly developed leaves per time step and layer $\left(f_{\text {new }}\right)$. Furthermore, deciduous PFTs shed all $\mathrm{CUO}$ at the end of the growing season and grow undamaged leaves the next spring. Evergreen PFTs shed proportionate amounts of CUO during the entire year whenever new leaves are grown.
The full canopy cumulative uptake of $\mathrm{O}_{3}$ is calculated by summing $\mathrm{CUO}_{1}$ over all present canopy layers $(n)$ :

$\mathrm{CUO}=\sum_{l=1}^{n} \mathrm{CUO}_{l}$

The $\mathrm{CUO}_{1}$ is used to approximate the damage to net photosynthesis $\left(A_{\mathrm{n}}\right)$ by using the damage relationship of Wittig et al. (2007):

$d_{1}^{\mathrm{O}_{3}}=\frac{0.22 \mathrm{CUO}_{1}+6.16}{100}$,

where the factor 100 scales the percentage values of damage to fractions. Net photosynthesis accounting for ozone damage $\left(A_{\mathrm{n}}^{\mathrm{O}_{3}}\right)$ is then calculated by subtracting the damage fraction from the undamaged value of $A_{\mathrm{n}}$ :

$A_{\mathrm{n}, 1}^{\mathrm{O}_{3}}=A_{\mathrm{n}, 1}\left(1-d_{1}^{\mathrm{O}_{3}}\right)$.

Since $G_{\text {st }}$ and $A_{\mathrm{n}}$ are tightly coupled (see Eq. 5), a damage of $A_{\mathrm{n}}$ results in a simultaneous reduction in $G_{\text {st }}$. The canopyscale $\mathrm{O}_{3}$ flux into the leaf cavities $\left(F_{\mathrm{stC}}\right)$ is calculated by summing $F_{\mathrm{st}}$ of all canopy layers, similar to the aggregation of $A_{\mathrm{n}, 1}$ and $G_{\mathrm{st}}$ and $\mathrm{CUO}_{1}$. Canopy $\mathrm{O}_{3}$ concentration, $\mathrm{O}_{3}$ uptake, canopy cumulative $\mathrm{O}_{3}$ uptake (CUO), and damage to net photosynthesis are solved iteratively to account for the feedbacks between ozone damage, canopy conductance and canopy-air $\mathrm{O}_{3}$ concentrations.

Note that CUO and POD can be directly compared to estimates according to the LRTAP Convention (2010) notation when analysing only the top canopy layer (Mills et al., 2011b).

\subsection{Sensitivity analysis}

A sensitivity analysis is conducted to estimate the sensitivity of the modelled plant $\mathrm{O}_{3}$ uptake to the parameterisation of the model, to establish the robustness of the model, and to identify the most influential parameters. Three parameters (ground-surface resistance $\left(\hat{R}_{\mathrm{gs}}\right)$, external leaf resistance $\left(r_{\text {ext }}\right)$, and empirical constant $(b)$; see Eqs. 10, 6, and 9 respectively) and three modelled quantities (canopy conductance $\left(G_{\mathrm{c}}\right)$, aerodynamic resistance $\left(R_{\mathrm{a}}\right)$, and canopy-scale quasi-laminar layer resistance $\left(R_{\mathrm{b}}\right)$; see Eqs. 5,2$)$, with considerable uncertainty due to the underlying parameters used to calculate these quantities, are perturbed within $\pm 20 \%$ of their central estimate.

A set of 100 parameter combinations is created with a Latin hypercube sampling method (McKay et al., 1979), simultaneously perturbing all six parameter values (R package: FME; function: Latinhyper). For each parameter combination, a transient run (see Sect. 2.4) is performed creating an ensemble of estimates for the key prognostic variables $F_{\mathrm{stC}}$ (Eq. 13$), R_{\mathrm{c}}$ (Eq. 4), $V_{\mathrm{g}}$ (Eq. 2) and the $\mathrm{O}_{3}$ flux ratio $\left(F_{\mathrm{R}}\right)$ calculated as the ratio of $F_{\mathrm{stC}}$ and the total $\mathrm{O}_{3}$ flux to the surface $\left(F_{\mathrm{g}}\right.$, Eq. 1). 
The summer months June, July, and August (JJA) are selected from the simulation output and used for further analysis. For each prognostic variable $\left(F_{\mathrm{stC}}, R_{\mathrm{c}}, V_{\mathrm{g}}, F_{\mathrm{R}}\right)$, the sensitivity to changes in all six perturbed parameters/variables is estimated by calculating partial correlation coefficients (PCCs) and partial ranked correlation coefficients (PRCCs) (Helton and Davis, 2002). PCCs record the linear relationship between two variables where the linear effects of all other variables in the analysis are removed (Helton and Davis, 2002). In the case of nonlinear relationships, PRCCs can be used, which implies a rank transformation to linearise any monotonic relationship, such that the regression and correlation procedures as in the PCCs can follow (Helton and Davis, 2002). We estimate the magnitude of the parameter effect by creating mean summer values of the four prognostic variables for each sensitivity run, and regressing these values against the corresponding parameter/variable scaling values of the respective model run.

\subsection{Modelling protocol and data for site-level simulations}

The site-level simulations (single-point simulations) at the FLUXNET sites are run using observed metrological forcing, soil properties, and land cover from the La Thuile Dataset (http://fluxnet.fluxdata.org/data/la-thuile-dataset/) of the FLUXNET project (Baldocchi et al., 2001). Data on atmospheric $\mathrm{CO}_{2}$ concentrations are obtained from Sitch et al. (2015). Reduced and oxidised nitrogen deposition in wet and dry forms and hourly $\mathrm{O}_{3}$ concentrations at $45 \mathrm{~m}$ height are provided by the EMEP model (see Sect. 2.5).

OCN is brought into equilibrium in terms of the terrestrial vegetation and soil carbon and nitrogen pools in a first step with the forcing of the year 1900. In the next step, the model is run with a progressive simulation of the period 1900 up until the start year of the respective site. For this period atmospheric $\mathrm{O}_{3}$ and $\mathrm{CO}_{2}$ concentrations as well as $\mathrm{N}$ deposition of the respective simulated years are used. Due to lack of observed climate for the sites for this period, the site-specific observed meteorology from recent years is iterated for these first two steps. The observation years (see Table A1) are simulated with the climate and atmospheric conditions ( $\mathrm{N}$ deposition, $\mathrm{CO}_{2}$ and $\mathrm{O}_{3}$ concentrations) of the respective years.

For the evaluation of the model output, net ecosystem exchange (NEE), and latent heat flux (LE), as well as meteorological observations, are obtained for 11 evergreen needleleaved forest sites, 10 deciduous broadleaved forest sites, and $5 \mathrm{C}_{3}$ grassland sites in Europe (see Table A1) from the La Thuile Dataset of the FLUXNET project (Baldocchi et al., 2001). Leaf area indices (LAIs) based on discrete point measurements are obtained from the La Thuile ancillary database.

NEE measurements are used to estimate gross primary production (GPP) by the flux-partitioning method according to (Reichstein et al., 2005). Canopy conductance $\left(G_{\mathrm{c}}\right)$ is derived by inverting the Penman-Monteith equation given the observed LE and atmospheric conditions as described in Knauer et al. (2015).

The half-hourly FLUXNET and model fluxes are filtered prior to deriving average growing-season fluxes (bud break to litter fall) to reduce the effect of model biases on the modeldata comparison. Night-time and morning/evening hours are excluded by removing data with lower than $20 \%$ of the daily maximum shortwave downward radiation. To avoid any biases associated with the soil moisture or atmospheric drought response of OCN, we further exclude data points with a modelled soil moisture constraint factor (range between 0 and 1) below 0.8 and an atmospheric vapour pressure deficit larger than $0.5 \mathrm{kPa}$.

Daily mean values are calculated from the remaining time steps only where both modelled and observed values are present. The derived daily values are furthermore constrained to the main growing season by excluding days where the daily GPP is less than $20 \%$ of the yearly maximum daily GPP.

To derive representative diurnal cycles, data for the month July are filtered for daylight hours (taken as incoming shortwave radiation $\geq 100 \mathrm{~W} \mathrm{~m}^{-2}$ ), with periods of soil or atmospheric drought stress excluded as above. This is done for modelled $F_{\mathrm{stC}}, R_{\mathrm{c}}, V_{\mathrm{g}}$, and $F_{\mathrm{R}}$ and for both modelled and FLUXNET observed GPP and $G_{\mathrm{c}}$.

\subsection{Modelling protocol and data for regional simulations}

For the regional simulations, OCN is run at a spatial resolution of $0.5^{\circ} \times 0.5^{\circ}$ on a spatial domain focused on Europe. Daily meteorological forcing (temperature, precipitation, shortwave and longwave downward radiation, atmospheric specific humidity, and wind speed) for the years 1961 to 2010 is obtained from RCA3 regional climate model (Samuelsson et al., 2011; Kjellstrom et al., 2011), nested in the ECHAM5 model (Roeckner et al., 2006), and has been bias-corrected for temperatures and precipitation using the CRU climatology (New et al., 1999). Reduced and oxidised nitrogen deposition in wet and dry forms and $\mathrm{O}_{3}$ concentrations at $45 \mathrm{~m}$ height for the same years are obtained from the EMEP model, which is also run with RCA3 meteorology (as in Simpson et al., 2014b). Emissions for the EMEP runs in current years are as described in Simpson et al. (2014b), and are scaled back to 1900 using data from UNECE and van Aardenne et al. (2001) - see Appendix B. Further details of the EMEP model setup for this grid and meteorology can be found in Simpson et al. (2014b) and Engardt et al. (2017). For OCN, land cover, soil, and $\mathrm{N}$ fertiliser application are used as in Zaehle et al. (2011) and kept at 2005 values throughout the simulation. Data on atmospheric $\mathrm{CO}_{2}$ concentrations are obtained from Sitch et al. (2015).

OCN is brought into equilibrium in terms of the terrestrial vegetation and soil carbon and nitrogen pools by randomly 
iterating the forcing from the period 1961-1970. This is followed by a simulation for the years 1961-2011 with timevarying climate and atmospheric conditions ( $\mathrm{N}$ deposition, $\mathrm{CO}_{2}$, and $\mathrm{O}_{3}$ concentrations) but with static land cover and land-use information (kept at year 2005 levels). An upscaled FLUXNET-MTE product of GPP (Jung et al., 2011), using the model tree ensembles (MTE) machine learning technique, is used to evaluate modelled GPP.

\subsection{Impacts of using the ozone deposition scheme}

In contrast to other terrestrial biosphere models, the $\mathrm{OCN}$ ozone module accounts for the effects of aerodynamic, stomatal and non-stomatal resistance to $\mathrm{O}_{3}$ deposition. Due to these resistances, the deposition of $\mathrm{O}_{3}$ to leaf level is reduced, and the canopy $\mathrm{O}_{3}$ concentration is lower than the atmospheric $\mathrm{O}_{3}$ concentration. Thus, using such a deposition scheme reduces modelled $\mathrm{O}_{3}$ uptake into plants and accumulation. To get an estimate of the magnitude of this impact we compare simulations with the standard deposition scheme as described above (D) with a simulation where $\mathrm{O}_{3}$ surface resistance is only determined by stomatal resistance and the non-stomatal depletion of $\mathrm{O}_{3}$ is zero (D-STO), as well as a further simulation where no deposition scheme is used and the canopy $\mathrm{O}_{3}$ concentration is equal to the atmospheric concentration (ATM).

\section{Results}

\subsection{Evaluation against daily eddy-covariance data}

Figure 1 a shows that, for most sites, modelled and observation-based GPP agree well (see Table A2 for $R^{2}$ and RMSE values). The standard deviation is larger for the observation-based estimates because of the high level of noise in the eddy-covariance data. For sites dominated by needle-leaved trees, the modelled and observation-based GPP values are very close, with only slight under- and overestimates by the model at some sites. At sites dominated by broadleaved trees, modelled GPP deviates more strongly from the observation-based GPP, underestimating the observations in 7 out of 10 cases. However, the results are within the range of standard deviation except for the drought-prone PT-Mil site (see Fig. A1a for an explicit site comparison). At $\mathrm{C}_{3}$ grassland sites, modelled GPP is in good agreement with the observation-based GPP except for AT-Neu, which has the highest mean GPP of all sites observed by FLUXNET with a large standard deviation, which may reflect the effect of site management (e.g. mowing and fertilisation), for which no data were readily available as model forcing.

When comparing modelled and observed latent heat flux (LE), the model fits the observations best at the needle-leaved forest sites (Fig. 1c). However, LE is overestimated at 9 out of 10 broadleaved forest sites but remains within the range of the large observational standard deviation. At sites dom- inated by $\mathrm{C}_{3}$ grasses the modelled LE differs considerably from the observed value, at two sites overestimating and two underestimating the fluxes, again within the observational standard deviation.

In agreement with the comparison of GPP and LE, the comparison of modelled to observation-based canopy conductance $\left(G_{\mathrm{c}}\right)$ shows the best agreement for sites dominated by needle-leaved trees (Fig. 1b). At sites dominated by broadleaved trees, the modelled $G_{\mathrm{c}}$ varies more widely from the FLUXNET $G_{\mathrm{c}}$. The modelled $G_{\mathrm{c}}$ at sites dominated by $\mathrm{C}_{3}$ grasses is in very good agreement with FLUXNET $G_{\mathrm{c}}$, with slight overestimation of $G_{\mathrm{c}}$ at two out of three sites, except for the DE-Meh site, where means differ outside the standard deviation (see Fig. A1b).

The comparison of the average modelled summertime LAI and point measurements at the FLUXNET illustrates that the variability in the measured LAI is much greater than that of OCN (Fig. 1d). The modelled LAI values approach lightsaturating, maximum LAI values and are not able to reproduce between-site differences in, for example, the growth stage, site history, or maximum possible LAI values. Furthermore, it should be borne in mind that the observed LAI values are averages of point measurements, which are not necessarily representative of the modelled time period, and that the model had not been parameterised specifically for the sites. Modelled GPP depends not only on LAI but also on light availability, temperature, and soil moisture. The much better represented values of GPP, $G_{\mathrm{c}}$, and LE compared to FLUXNET data (Fig. 1a-c) indicate that OCN is able to adequately transform available energy into carbon uptake and water loss and thus simulate key variables impacting ozone uptake within a reasonable range.

\subsection{Mean diurnal cycles of key $\mathrm{O}_{3}$ parameters.}

For further evaluation of the modelled $\mathrm{O}_{3}$ uptake, we analysed the diurnal cycles of $\mathrm{O}_{3}$ uptake $\left(F_{\mathrm{stC}}\right), \mathrm{O}_{3}$ surface resistance $\left(R_{\mathrm{c}}\right), \mathrm{O}_{3}$ deposition velocity $\left(V_{\mathrm{g}}\right)$, and flux ratio $\left(F_{\mathrm{R}}\right)$ ) as well as GPP and $G_{\mathrm{c}}$. We selected three sites (a broadleaved, a needle-leaved, and a $\mathrm{C}_{3}$ grass site) based on the selection criteria that modelled and FLUXNET GPP and LAI agree well and a minimum of five observation years is available to reduce possible biases from the inability of the model to simulate short-term variations from the mean. The selected sites are a temperate broadleaved summer green forest (IT-Ro1), a boreal needle-leaved evergreen forest (FI$\mathrm{Hyy})$, and a temperate $\mathrm{C}_{3}$ grass land (CH-Oe1). We evaluate modelled GPP and $G_{\mathrm{c}}$ against observations from the FLUXNET sites. The modelled mean diurnal cycles of $\mathrm{O}_{3}$ related variables $\left(F_{\mathrm{stC}}, R_{\mathrm{c}}, V_{\mathrm{g}}, F_{\mathrm{R}}\right)$ are compared to reported values in the literature since we did not have access to sitespecific observations.

Modelled and observed mean diurnal cycles of GPP and $G_{\mathrm{c}}$ are in general agreement at the three selected FLUXNET sites (see Fig. 2a, g, m and b, h, n) with particularly good 

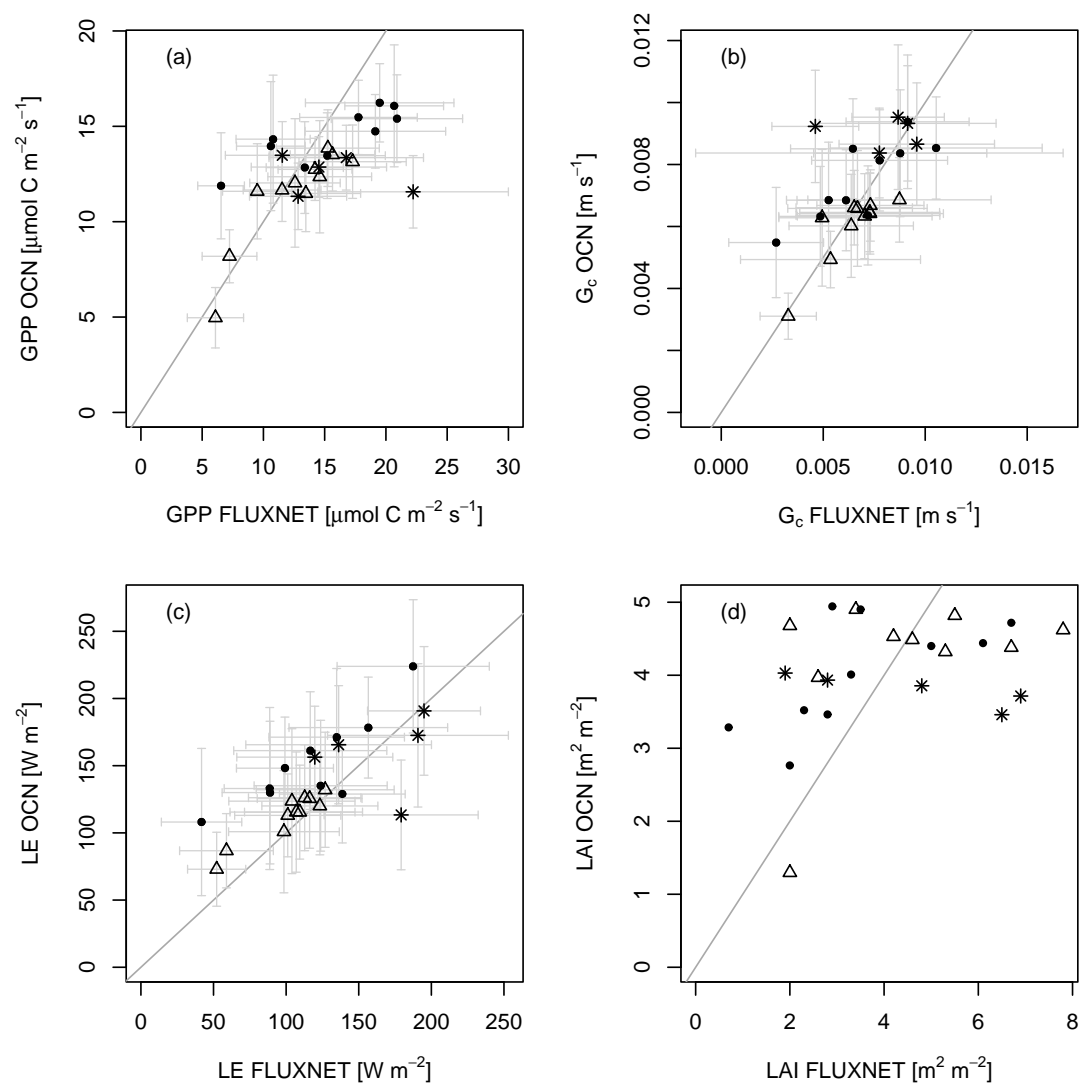

Figure 1. Comparison of measured (a) GPP, (b) canopy conductance $\left(G_{\mathrm{c}}\right)$, (c) latent heat flux (LE), and (d) LAI at 26 European FLUXNET sites and simulations by OCN. Displayed are means and standard deviations of daily means of the measuring/simulation period, with the exception of FLUXNET-derived LAI, which is based on point measurements. Dots symbolise sites dominated by broadleaved trees, triangles sites dominated by needle-leaved trees, and asterisks sites dominated by $\mathrm{C}_{3}$ grasses. The grey line constitutes the $1: 1$ line.

agreement for the mean diurnal cycle of GPP at the needleleaved site FI-Hyy, where the hourly means are very close and the observational standard deviation is narrow (see Fig. $2 \mathrm{~g}$ ). At the grassland site IT-Ro1 the overall daytime magnitude of the fluxes is reproduced in general except for the observed afternoon reduction in GPP (see Fig. 2a). The modelled hourly values fall in the range of the observed values. Modelled and observation-based hourly means of GPP at the site $\mathrm{CH}-\mathrm{Oe} 1$ agree well except for the evening hours, where the observed values increase again. The mean diurnal cycles of $G_{\mathrm{c}}$ derived from the FLUXNET data are again best matched at the site FI-Hyy, whereas the model generally overestimates the diurnal cycle of $G_{\mathrm{c}}$ slightly at the site IT-Ro1, and overestimates peak $G_{\mathrm{c}}$ at the $\mathrm{CH}-\mathrm{Oe} 1$ site. The fact that $\mathrm{OCN}$ does not always simulate the observed midday depression of $G_{\mathrm{c}}$, suggests that the response of stomata to atmospheric and soil drought in OCN requires further evaluation and improvement. Similar to the daily mean values (see Fig. 1a, b), the mean hourly values show the best match of GPP and $G_{\mathrm{c}}$ for the needle-leaved tree site and stronger deviations for the sites covered by broadleaved trees and $\mathrm{C}_{3}$ grasses.
The stomatal $\mathrm{O}_{3}$ uptake $F_{\text {stC }}$ (Fig. $2 \mathrm{c}$, i, o) is close to zero during night-time, when the stomata are assumed to be closed, because gross photosynthesis is zero. At FI-Hyy and $\mathrm{CH}-\mathrm{Oe} 1$, peak uptake occurred at noon, when photosynthesis (Fig. 2g, m) and stomatal conductance (Fig. 2h, n) are highest, at values between 8 and $9 \mathrm{nmol} \mathrm{m}^{-2} \mathrm{~s}^{-1}$. At the Italian site IT-Ro1, maximum uptake occurs in the afternoon hours around $15 \mathrm{~h}$, with much larger standard deviation compared to the other two sites (Fig. 2c). The magnitude of stomatal $\mathrm{O}_{3}$ uptake corresponds well to some values reported, for example, for crops (Gerosa et al., 2003, 2004; daily maxima of 4-9 nmol m${ }^{-2} \mathrm{~s}^{-1}$ ) and holm oak (Vitale et al., 2005; approx. $\left.7-8 \mathrm{nmol} \mathrm{m}^{-2} \mathrm{~s}^{-1}\right)$. Lower daily maximum values have been reported for an evergreen Mediterranean forest dominated by Holm Oak of $4 \mathrm{nmol} \mathrm{m}^{-2} \mathrm{~s}^{-1}$ under dry weather conditions (Gerosa et al., 2005) and 1-6 nmol m${ }^{-2} \mathrm{~s}^{-1}$ for diverse southern European vegetation types (Cieslik, 2004). Much higher values are reported for Picea abies $\left(50-90 \mathrm{nmol} \mathrm{m}^{-2} \mathrm{~s}^{-1}\right.$ ), Pinus cembra (10-50 $\left.\mathrm{nmol} \mathrm{m}^{-2} \mathrm{~s}^{-1}\right)$, and Larix decidua (10$40 \mathrm{nmol} \mathrm{m}^{-2} \mathrm{~s}^{-1}$ ) at a site near Innsbruck, Austria (Wieser et al., 2003), where canopy $\mathrm{O}_{3}$ uptake was estimated by sapflow measurements in contrast to the studies mentioned be- 

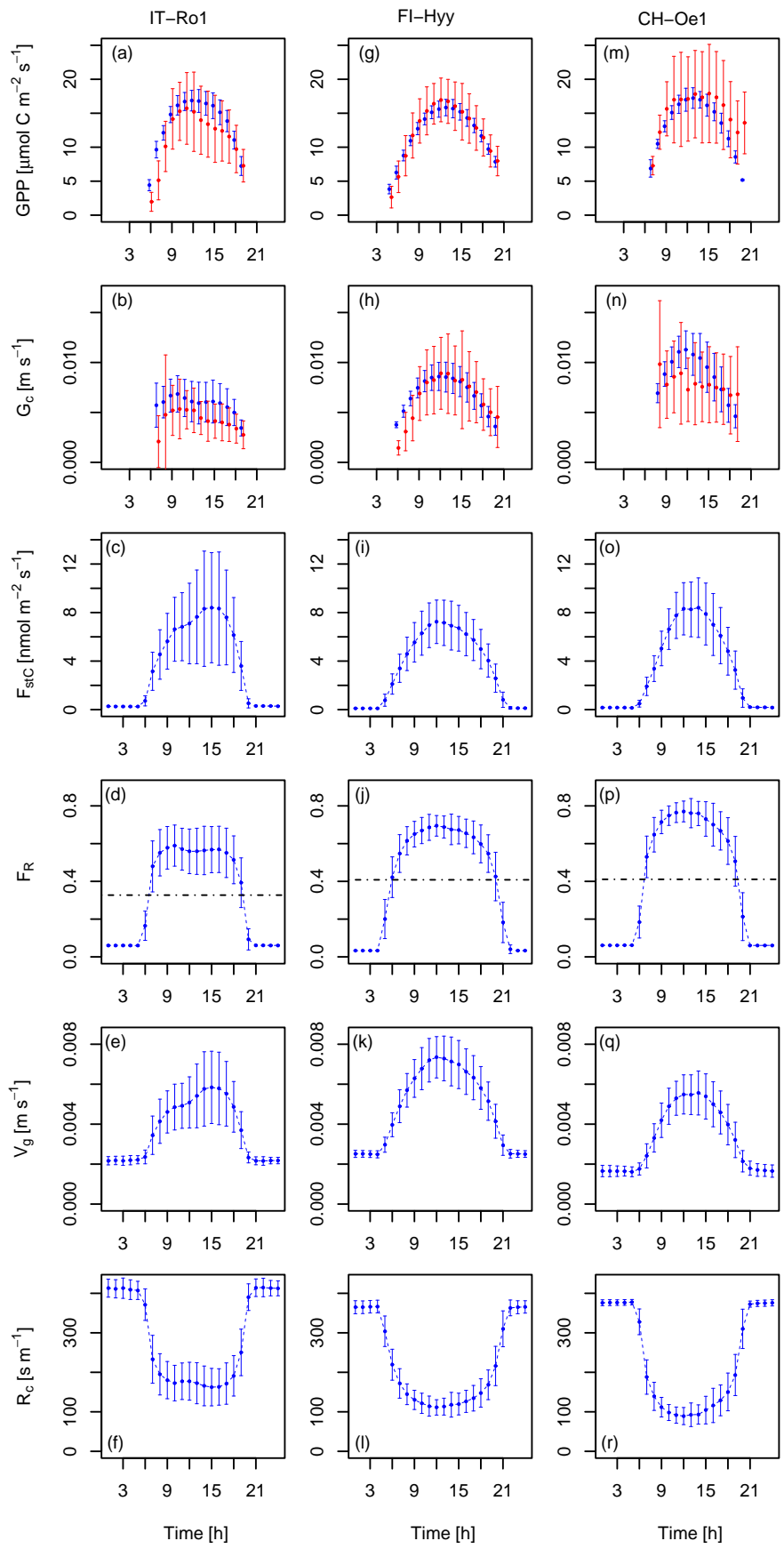

Figure 2. Simulated and observed hourly means over all days of the months of July of 2002-2006 for CH-Oe1 and IT-Ro1, as well as for 2001-2006 for FI-Hyy. Plotted are mean hourly values (local time) of (a, g, m) GPP (blue: OCN; red: FLUXNET), (b, h, n) canopy conductance $\left(G_{\mathrm{c}}\right)$ (blue: OCN; red: FLUXNET), $(\mathbf{c}, \mathbf{i}, \mathbf{o}) \mathrm{O}_{3}$ uptake $\left(F_{\mathrm{stC}}\right),(\mathbf{d}, \mathbf{j}, \mathbf{p})$ the flux ratio $\left(F_{\mathrm{R}}\right),(\mathbf{e}, \mathbf{k}, \mathbf{q}) \mathrm{O}_{3}$ deposition velocity $\left(V_{\mathrm{g}}\right)$, and $(\mathbf{f}, \mathbf{l}, \mathbf{r}) \mathrm{O}_{3}$ surface resistance $\left(R_{\mathrm{C}}\right)$. The error bars indicate the standard deviation from the hourly mean. The dotted line in panels $(\mathbf{d})$, $(\mathbf{j})$, and (p) indicates the daily mean value.

fore where the eddy-covariance technique was applied. The much higher $F_{\mathrm{stC}}$ values in that study result from much higher canopy conductances to $\mathrm{O}_{3}\left(G_{\mathrm{c}}^{\mathrm{O}_{3}}\right)$, which are up to 12 times higher than the modelled $G_{\mathrm{c}}^{\mathrm{O}_{3}}$ values in our study (see Fig. 2, $G_{\mathrm{c}}^{\mathrm{O}_{3}}=\frac{G_{\mathrm{c}}}{1.51}$ ).
The ratio between the stomatal $\mathrm{O}_{3}$ uptake and the total surface uptake $\left(F_{\mathrm{R}}\right)$ is close to zero during night-time hours and increases steeply in the morning hours (Fig. $2 \mathrm{~d}, \mathrm{j}, \mathrm{p}$ ). The $24 \mathrm{~h}$ average is approximately 0.3 for IT-Ro 1 and 0.4 for FIHyy and CH-Oe1 (Fig. 2d, j, p). Peak hourly mean values 
are close to 0.6 at IT-Ro1, around 0.7 at FI-Hyy, and close to 0.8 at $\mathrm{CH}-\mathrm{Oe} 1$. These values are comparable to the ratios reported for crops (Gerosa et al., 2004; Fowler et al., 2009; 0.5-0.6), Norway spruce (Mikkelsen et al., 2004; 0.30.33 ), and various southern European vegetation types (Cieslik, 2004; 0.12-0.69). The modelled flux ratios here show slightly higher daily maximum flux ratios than reported in the listed studies. Daily mean flux ratios are well within the reported range.

The modelled deposition velocities $V_{\mathrm{g}}$ are lowest during night-time, with values of approximately $0.002 \mathrm{~m} \mathrm{~s}^{-1}$ (Fig. 2e, k, q). These values increase to maximum hourly means of $0.006-0.007 \mathrm{~m} \mathrm{~s}^{-1}$ during daytime. These values compare well with reported values of deposition velocities, which range from 0.003 to $0.009 \mathrm{~m} \mathrm{~s}^{-1}$ at noon (Gerosa et al., 2004) for a barley field and are approximately $0.006 \mathrm{~m} \mathrm{~s}^{-1}$ at noon for a wheat field (Tuovinen et al., 2004) and approximately $0.009 \mathrm{~m} \mathrm{~s}^{-1}$ at noon at a potato field (Coyle et al., 2009). The estimates for FI-Hyy also agree well with maximum deposition velocities reported for Scots pine site of $0.006 \mathrm{~m} \mathrm{~s}^{-1}$ (Keronen et al., 2003; Tuovinen et al., 2004) and noon values from Danish Norway spruce sites of 0.006-0.010 $\mathrm{m} \mathrm{s}^{-1}$ (Mikkelsen et al., 2004; Tuovinen et al., 2001). Mean daytime deposition velocities of $0.006 \mathrm{~m} \mathrm{~s}^{-1}$ (range $0.003-0.008 \mathrm{~m} \mathrm{~s}^{-1}$ ) are reported at a Finnish mountain birch site (Tuovinen et al., 2001). Simulated monthly mean values of $V_{\mathrm{g}}$ differ substantially between the sites (see Fig. A2). When comparing the monthly means over all sites (Fig. A2 dashed line) of a functional group (broadleaved, needle-leaved, $\mathrm{C}_{3}$ grasses) to the ensemble mean of $15 \mathrm{CTMs}$ (Hardacre et al., 2015), the values simulated here are higher for needle-leaved tree sites. For broadleaved tree sites and grassland sites, higher values, but which are still within the observed ensemble range, are found for the summer months.

The modelled hourly mean $\mathrm{O}_{3}$ surface resistance $R_{\mathrm{c}}$ is highest during night-time, at approximately $400 \mathrm{~s} \mathrm{~m}^{-1}$, and decreases during daytime to values of $100-180 \mathrm{~s} \mathrm{~m}^{-1}$, where the lowest surface resistance of approximately $100 \mathrm{~s} \mathrm{~m}^{-1}$ is modelled at the grassland site CH-Oe1 (Fig. 2f, 1, r). These values are slightly higher than independent estimates (for grasses and crops obtained for other sites) of noon surface resistances ranging from 50 to $100 \mathrm{~s} \mathrm{~m}^{-1}$ (Padro, 1996; Coyle et al., 2009; Gerosa et al., 2004; Tuovinen et al., 2004). Tuovinen et al. (2004) reported noon values of approximately $140 \mathrm{sm}^{-1}$ for a Scots pine forest and $70-140 \mathrm{~s} \mathrm{~m}^{-1}$ for a Norway spruce forest site (Tuovinen et al., 2001), which compares well with the modelled $R_{\mathrm{c}}$ values at the needle-leaved forest site (FI-Hyy; Fig. 21). Higher noon values of approximately $250 \mathrm{~s} \mathrm{~m}^{-1}$ are reported at a Danish Norway spruce site (Mikkelsen et al., 2004). For a mountain birch forest, noon values of $110-140 \mathrm{~s} \mathrm{~m}^{-1}$ (Tuovinen et al., 2001) are observed which is slightly lower than the modelled value at the IT-Ro1 site (dominated by broadleaved tree PFT).
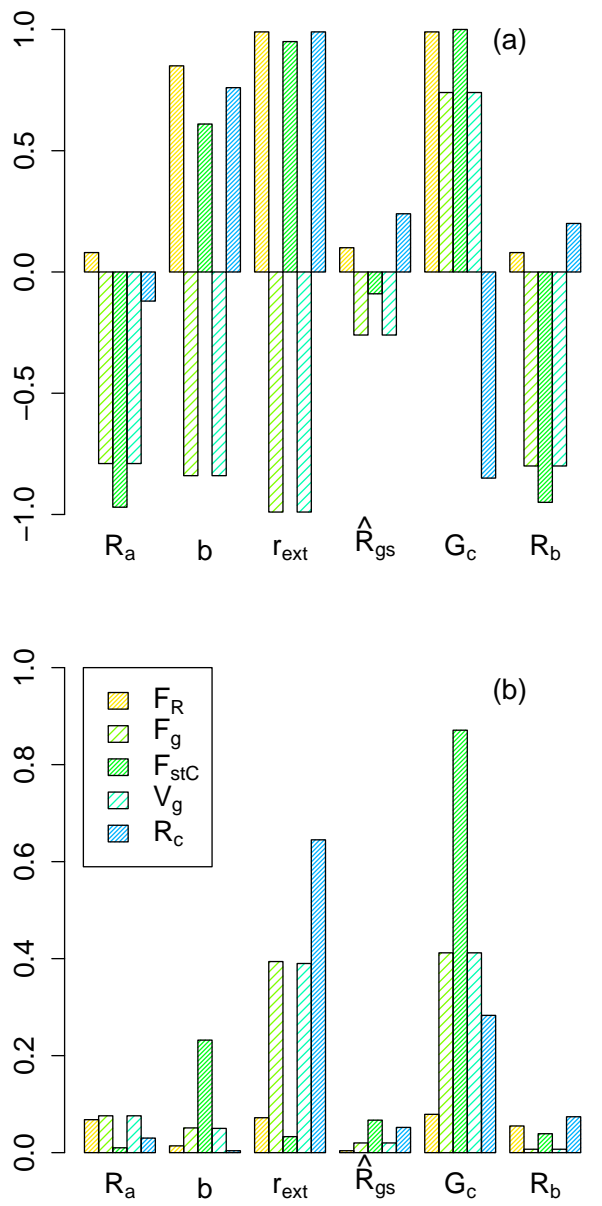

Figure 3. (a) Mean partial correlation coefficients and (b) strength of the correlation in $\%$ per $\% . R_{\mathrm{a}}, b, r_{\mathrm{ext}}, \hat{R}_{\mathrm{gs}}$, and $G_{\mathrm{c}}$ are perturbed within $\pm 20 \%$ of their central estimate. Results from simulations at the FLUXNET site FI-Hyy for the simulation period 2001-2006.

\subsection{Sensitivity analysis}

We assess the sensitivity of the modelled $\mathrm{O}_{3}$ uptake and deposition, represented by $F_{\mathrm{g}}, F_{\mathrm{stC}}, V_{\mathrm{g}}$, and $R_{\mathrm{c}}$, to uncertainty in six weakly constrained variables and parameters of the $\mathrm{O}_{3}$ deposition scheme $\left(R_{\mathrm{a}}, b, r_{\mathrm{ext}}, \hat{R}_{\mathrm{gs}}, G_{\mathrm{c}}\right.$, and $\left.R_{\mathrm{b}}\right)$. Figure $3 \mathrm{a}$ shows, for example, the results for the boreal needle-leaved forest FI-Hyy. As expected, all uptake/deposition variables, except for the flux ratio $\left(F_{\mathrm{R}}\right)$ are negatively correlated with the aerodynamic resistance $R_{\mathrm{a}}$, which describes the level of decoupling of the atmosphere and land surface. Increasing $R_{\mathrm{a}}$ decreases the canopy internal $\mathrm{O}_{3}$ concentration and hence stomatal $\left(F_{\mathrm{stC}}\right)$ and total $\left(F_{\mathrm{g}}\right)$ deposition as well as the deposition velocity $\left(V_{\mathrm{g}}\right)$. The flux ratio $F_{\mathrm{R}}$ is slightly positively correlated with changes in $R_{\mathrm{a}}$ due to the stronger negative correlation of $F_{\mathrm{stC}}$ relative to $F_{\mathrm{g}}$.

In decreasing order, but as expected, the level of external leaf resistance $\left(r_{\text {ext }}\right)$, the scaling factor $b$ (Eq. 9), the soil resistance $\left(\hat{R}_{\mathrm{gs}}\right)$, and the canopy-scale quasi-laminar layer re- 

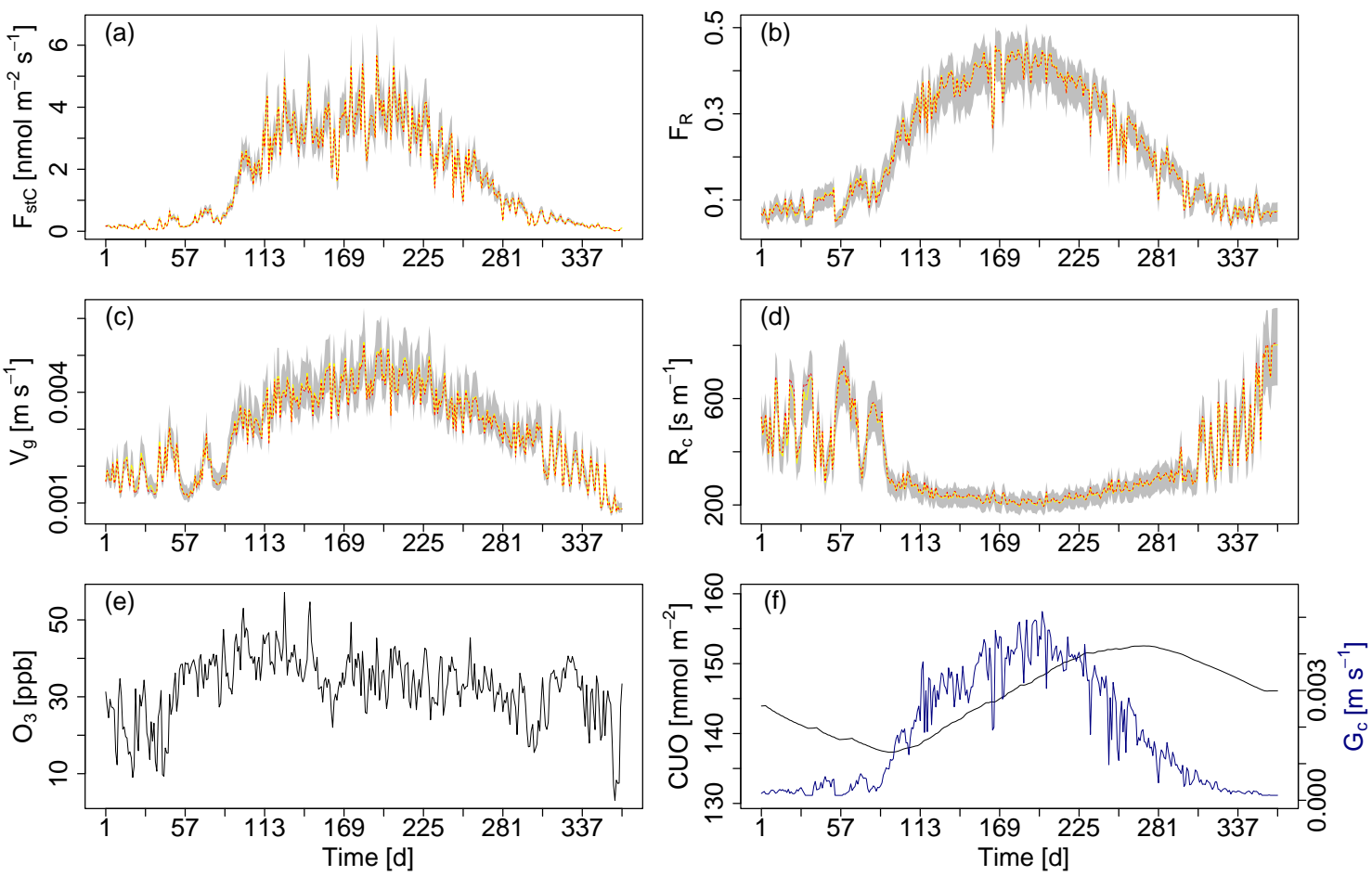

Figure 4. Ensemble range of key $\mathrm{O}_{3}$ uptake/deposition variables resulting from the perturbation of $R_{\mathrm{a}}, b, r_{\mathrm{ext}}, \hat{R}_{\mathrm{gs}}$, and $G_{\mathrm{c}}$ within $\pm 20 \%$ of their central estimate. Shown are simulated daily mean values of (a) $\mathrm{O}_{3}$ uptake $\left(F_{\mathrm{stC}}\right)$, (b) the $\mathrm{O}_{3}$ flux ratio $\left(F_{\mathrm{R}}\right)$, (c) $\mathrm{O}_{3}$ deposition velocity $\left(v_{\mathrm{g}}\right)$ and $(\mathbf{d}) \mathrm{O}_{3}$ surface resistance $\left(R_{\mathrm{c}}\right)$ for the boreal needle-leaved evergreen forest at the finish FLUXNET site FI-Hyy for the year 2001. Red dashed: unperturbed model; yellow: median of all sensitivity runs; light-grey area: min-max range of all sensitivity runs. Simulated daily mean values for the respective site and year of (e) atmospheric $\mathrm{O}_{3}$ concentrations $\mathrm{O}_{3}$ and (f) cumulative uptake of $\mathrm{O}_{3}$ (CUO) and canopy conductance $G_{\mathrm{c}}$.

sistance $\left(R_{\mathrm{b}}\right)$ increase $R_{\mathrm{c}}$ and consequently reduce $F_{\mathrm{g}}$ and $V_{\mathrm{g}}$. Reducing the non-stomatal deposition by increasing $r_{\mathrm{ext}}$, $b, \hat{R}_{\mathrm{gs}}$, and $R_{\mathrm{b}}$ increases the canopy internal $\mathrm{O}_{3}$ concentration and thus stomatal $\mathrm{O}_{3}$ uptake $\left(F_{\mathrm{stC}}\right)$. The combined effects of a reduction in total deposition $F_{\mathrm{g}}$ and an increase in $F_{\text {stC }}$ cause a positive correlation of $F_{\mathrm{R}}$ to $r_{\mathrm{ext}}, b, \hat{R}_{\mathrm{gs}}$, and $R_{\mathrm{b}}$.

Increasing canopy conductance $\left(G_{\mathrm{c}}\right)$ increases stomatal $\mathrm{O}_{3}$ uptake $\left(F_{\mathrm{stC}}\right)$ and thereby also increases $V_{\mathrm{g}}$ and $F_{\mathrm{g}}$. The increased total $\mathrm{O}_{3}$ uptake $\left(F_{\mathrm{g}}\right)$ decreases the surface resistance to $\mathrm{O}_{3}$ uptake $R_{\mathrm{c}}$, resulting in a negative correlation of $R_{\mathrm{c}}$ with $G_{\mathrm{c}}$. The stronger increase in $F_{\mathrm{stC}}$ relative to $F_{\mathrm{g}}$ results in a positive correlation of $F_{\mathrm{R}}$.

Despite these partial correlations, only changed values for $r_{\text {ext }}$ and $G_{\mathrm{c}}$ have a notable effect on the predicted fluxes (Fig. 3b), whereas for the other factors $\left(R_{\mathrm{a}}, b\right.$, and $\left.\hat{R}_{\mathrm{gs}}\right)$ the impact on the simulated fluxes is less than $0.1 \%$ due to a $1 \%$ change in the variables/parameters of the deposition scheme.

The flux ratio $F_{\mathrm{R}}$ is very little affected by varying $r_{\mathrm{ext}}$ and $G_{\mathrm{c}}$.

Notwithstanding the perturbations, all four $\mathrm{O}_{3}$ related flux variables show a fairly narrow range of simulated values (Fig. 4). For all four variables the unperturbed model and the ensemble mean lie on top of each other (see dashed red and yellow line in Fig. 4a-d). The seasonal course of the surface resistances and fluxes is maintained. The simulations show a strong day-to-day variability in $F_{\mathrm{stC}}$, which is conserved with different parameter combinations and which is largely driven by the day-to-day variations in $G_{\mathrm{c}}$ and the atmospheric $\mathrm{O}_{3}$ concentration (see Fig. $4 \mathrm{f}$ and e respectively). Ozone uptake by the leaves reduces the $\mathrm{O}_{3}$ surface resistance during the growing season such that $R_{\mathrm{c}}$ becomes lowest. The cumulative uptake of $\mathrm{O}_{3}(\mathrm{CUO})$ is lowest at the beginning of the growing season but not zero because the evergreen pine at the Hyytiälä site accumulates $\mathrm{O}_{3}$ over several years (Fig. 4f). The CUO increases during the growing season and declines in autumn, when a larger fraction of old needles are shed.

The minor impact of the perturbations on the simulated $\mathrm{O}_{3}$ uptake and deposition variables suggests that the calculated $\mathrm{O}_{3}$ uptake is relatively robust against uncertainties in the parameterisation of some of the lesser known surface properties.

\subsection{Regional simulations}

We used the model to simulate the vegetation productivity, $\mathrm{O}_{3}$ uptake, and associated ozone damage of plant produc- 
tion over Europe for the period 2001-2010 (see Sect. 2.5 for modelling protocol).

Simulated mean annual GPP for the years 1982-2011 shows in general good agreement with an independent estimate of GPP based on upscaled eddy-covariance measurements (MTE; see Sect. 2.5), with OCN on average underestimating GPP by $16 \%$ (European mean). A significant exception are cropland dominated areas (Fig. 5) in parts of eastern Europe, southern Russia, Turkey, and northern Spain, which show consistent overestimation of GPP by OCN of 400$900 \mathrm{~g} \mathrm{C} \mathrm{m}^{-2} \mathrm{yr}^{-1}$ (58\% overestimation on average). Regions with a strong disagreement coincide with high simulated LAI values by OCN and a higher simulated GPP in summer compared to the summer GPP by MTE. In addition, OCN simulates a longer growing season for croplands since sowing and harvest dates are not considered. It is worth noting, nevertheless, that there are no FLUXNET stations present in the regions of disagreement hotspots, making it difficult to assess the reliability of the MTE product in this region.

North of $60^{\circ} \mathrm{N}$, OCN has the tendency to produce lower estimates of GPP than inferred from the observationbased product, which is particularly pronounced in lowproductivity mountain regions of Norway and Sweden. It is unclear whether this bias is indicative of a $\mathrm{N}$ limitation that is too strong in the OCN model.

Average decadal $\mathrm{O}_{3}$ concentrations generally increase from northern to southern Europe (Fig. 6a) and with increasing altitude, with local deviations from this pattern in centres of substantial air pollution. The pattern of foliar $\mathrm{O}_{3}$ uptake differs distinctly from that of the $\mathrm{O}_{3}$ concentrations, showing highest uptake rates in central and eastern Europe and parts of southern Europe (Fig. 6b), associated with centres of high rates of simulated gross primary production (Fig. 5a) and thus canopy conductance. The cumulative $\mathrm{O}_{3}$ uptake reaches values of $40-60 \mathrm{mmol} \mathrm{m}^{-2}$ in large parts of central Europe (Fig. 6c). The highest accumulation rates of $80-110 \mathrm{mmol} \mathrm{m}^{-2}$ are found in eastern Europe and parts of Scandinavia as well as in Italy, the Alps, and the Bordeaux region. The concentration-based exposure index AOT40 (Fig. 6d) shows a strong north-south gradient similar to the $\mathrm{O}_{3}$ concentration (Fig. 6a) and is distinctly different to the flux-based CUO pattern (Fig. 6c).

Simulated reduction in mean decadal GPP due to $\mathrm{O}_{3}$ range from 80 to $160 \mathrm{~g} \mathrm{C} \mathrm{m}^{-2} \mathrm{yr}^{-1}$ over large areas of central, eastern, and south-eastern Europe (Fig. 7a) and is generally largest in regions of high productivity. The relative reduction in GPP is fairly consistent across large areas in Europe and averages $6-10 \%$ (Fig. 7b). Higher reductions in relative terms are found in regions with high cover of $\mathrm{C}_{4}$ PFTs, e.g. the Black Sea area. Lower relative reductions are found in northern Europe and parts of southern Europe, where productivity is low and stomatal $\mathrm{O}_{3}$ uptake is reduced by, for example, low $\mathrm{O}_{3}$ concentrations or drought control on stomatal fluxes respectively. Slight increases or strong decreases in relative terms are found in regions with very small produc- tivity like in northern Africa and the mountainous regions of Scandinavia. A slight increase in GPP might be caused by feedbacks of GPP damage on LAI, canopy conductance, and soil moisture content such that water savings, for example, enable a prolonged growing season and thus a slightly higher GPP. Overall, simulated European productivity has been reduced from 10.6 to $9.8 \mathrm{PgCyr}^{-1}$ corresponding to a $7.6 \%$ reduction.

The $\mathrm{O}_{3}$-induced reductions in GPP are associated with a reduction in mean decadal transpiration rates of 8 $15 \mathrm{~mm} \mathrm{yr}^{-1}$ over large parts of central and eastern Europe (Fig. 7c). These reductions correspond to 3-6\% of transpiration in central Europe and 6-10\% in northern Europe. As expected, the relative reductions in transpiration rates are therefore slightly less than for GPP due to the role of aerodynamic resistance in controlling water fluxes in addition to canopy conductance. Very high reductions in transpiration are found in the eastern Black Sea area associated with strong reductions in GPP and in the mountainous regions of Scandinavia, where absolute changes in transpiration are very small. Regionally (in particular in eastern Spain, northern Africa, and around the Black Sea) lower reductions in transpiration or even slight increases are found (Fig. 7d). These are related to $\mathrm{O}_{3}$-induced soil moisture savings during the wet growing season, leading to lower water stress rates during the drier season. The very strong reduction in transpiration west of the Crimean Peninsula are related to the strong reductions in GPP mentioned above. Overall, simulated European mean transpiration has been reduced from 170.4 to $163.3 \mathrm{~mm}$ corresponding to a $4.2 \%$ reduction.

\subsection{Impacts of using the ozone deposition scheme}

At the FI-Hyy site the canopy $\mathrm{O}_{3}$ concentration, uptake and accumulated uptake (CUO) increases approximately 10 $15 \%$ for the D-STO model (non-stomatal depletion of $\mathrm{O}_{3}$ is zero) and $20-25 \%$ for the ATM model version (canopy $\mathrm{O}_{3}$ concentration is equal to the atmospheric concentration) compared to the standard deposition scheme (D) used here (Figs. 8a-c and A3). The exact values however are site- and PFT-specific (see Fig. A3 for the CH-Oe1 and IT-Ro1 site).

The regional impact of using the ozone deposition scheme on CUO is shown in Fig. 9. CUO substantially decreases for the D-STO (Fig. 9b) compared to the ATM model (Fig. 9a). Using the standard deposition model D (Fig. 9c) further reduces the CUO compared to the ATM version where the stomata respond directly to the atmospheric $\mathrm{O}_{3}$ concentration.

Calculating the canopy $\mathrm{O}_{3}$ concentration with the help of a deposition scheme that accounts for stomatal and nonstomatal $\mathrm{O}_{3}$ deposition thus reduces $\mathrm{O}_{3}$ accumulation in the vegetation. 

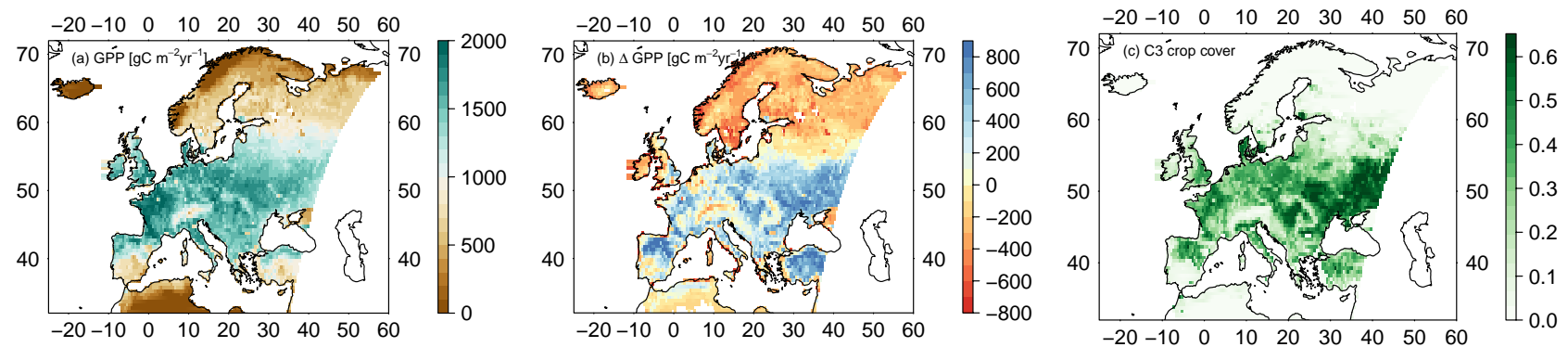

Figure 5. Europe-wide simulated GPP and difference between modelled GPP by OCN and a GPP estimate by a FLUXNET-MTE product. Plotted, for the years 1982-2011, are (a) the simulated mean GPP accounting for ozone damage in $\mathrm{g} \mathrm{Cm}^{-2} \mathrm{yr}^{-1}$, (b) the mean differences for OCN minus MTE GPP in $\mathrm{g} \mathrm{Cm}^{-2} \mathrm{yr}^{-1}$, and (c) the mean simulated grid cell cover of the $\mathrm{C}_{3}$-crop PFT in OCN, given as fractions of the total grid cell area.
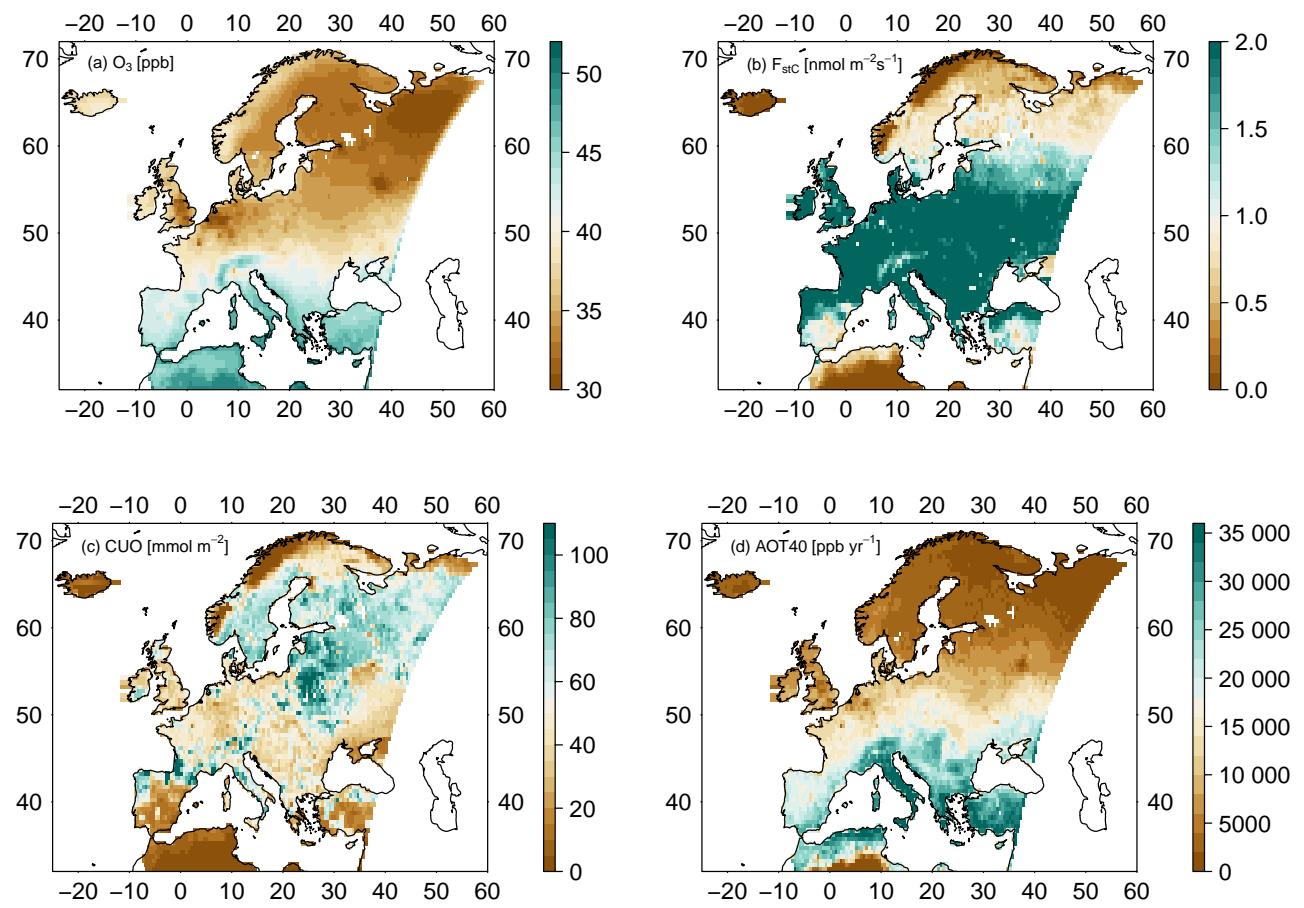

Figure 6. Mean decadal (a) $\mathrm{O}_{3}$ concentration (ppb), (b) canopy-integrated $\mathrm{O}_{3}$ uptake into the leaves (nmol m$\left.{ }^{-2} \mathrm{~s}^{-1}\right)$, (c) canopy-integrated cumulative uptake of $\mathrm{O}_{3}(\mathrm{CUO})\left(\mathrm{mmol} \mathrm{m}^{-2}\right)$, and (d) AOT40 $\left(\mathrm{ppm} \mathrm{yr}^{-1}\right)$, for Europe of the years 2001-2010.

\section{Discussion}

We extended the terrestrial biosphere model OCN by a scheme to account for the atmosphere-leaf transfer of $\mathrm{O}_{3}$ in order to better account for air pollution effects on net photosynthesis and hence regional to global water, carbon, and nitrogen cycling. This ozone deposition scheme calculates canopy $\mathrm{O}_{3}$ concentrations and uptake into the leaves depending on surface conditions and vegetation carbon uptake

Estimates of the regional damage to annual average GPP $(-7.6 \%)$ and transpiration $(-4.2 \%)$ simulated by $\mathrm{OCN}$ for 2001-2010 are lower than previously reported estimates. Meta-analyses suggest on average a $11 \%$ (Wittig et al., 2007) and a $21 \%$ (Lombardozzi et al., 2013) reduction in instantaneous photosynthetic rates. However, because of carry-over effects, this does not necessarily translate directly into reductions in annual GPP. Damage estimates using the CLM suggest GPP reductions of 10-25\% in Europe and $10.8 \%$ globally (Lombardozzi et al., 2015). Reductions in transpiration have been estimated as 5-20\% for Europe and 2.2\% globally (Lombardozzi et al., 2015). Lombardozzi et al. (2015), however, used fixed reductions of photosynthesis (12-20\%) independent of cumulative $\mathrm{O}_{3}$ uptake for two out of three simulated plant types. Damage was only related to cumulative $\mathrm{O}_{3}$ uptake for one plant type with a very small slope and hence little increase in damage due to increases in cu- 

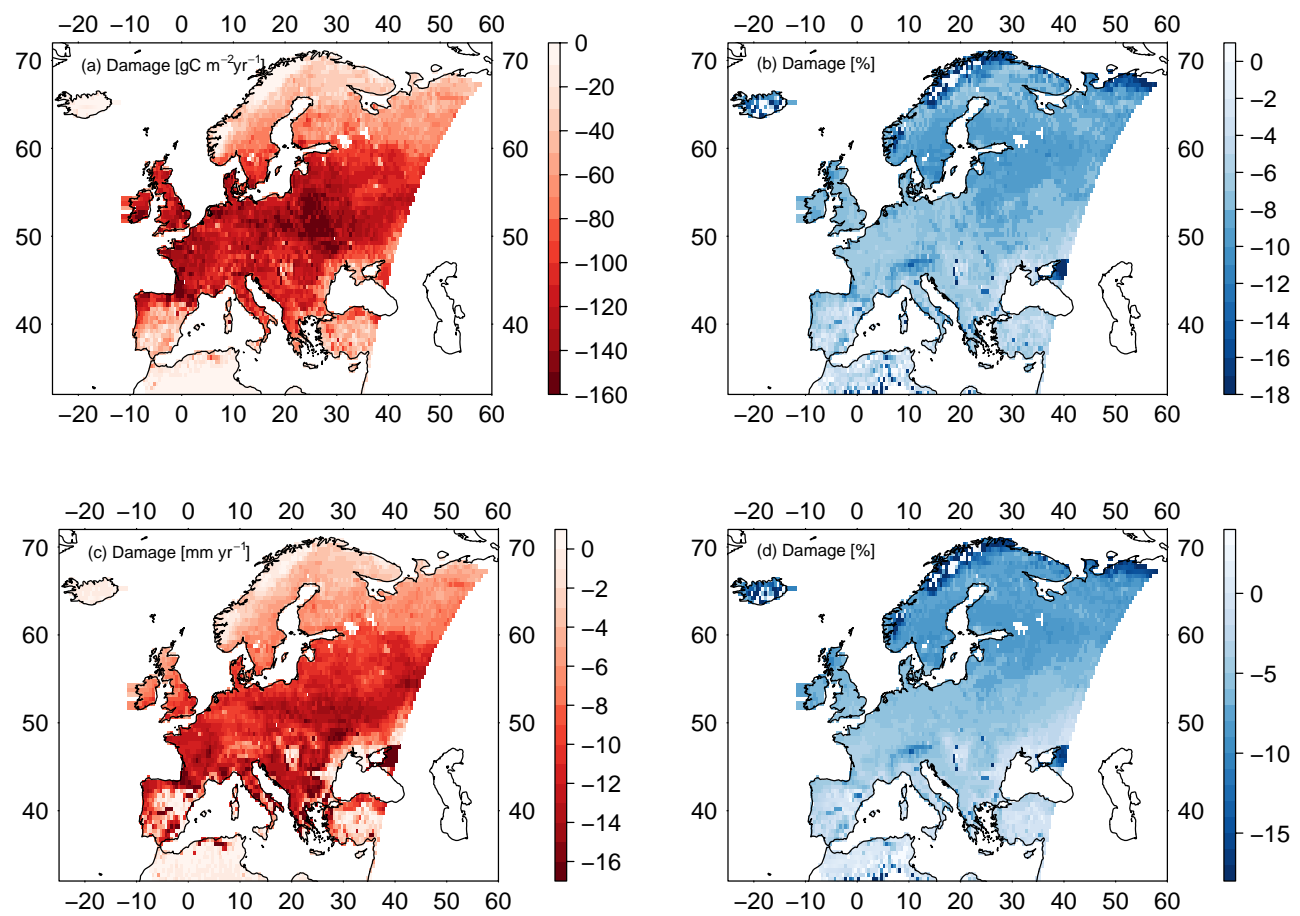

Figure 7. Mean decadal (a) reduction in GPP $\left(\mathrm{g} \mathrm{Cm}^{-2} \mathrm{yr}^{-1}\right)$, (b) percent reduction in GPP, (c) reduction in transpiration (mm $\left.\mathrm{mr}^{-1}\right)$, and (d) percent reduction in transpiration due to ozone damage averaged for the years 2001-2010.
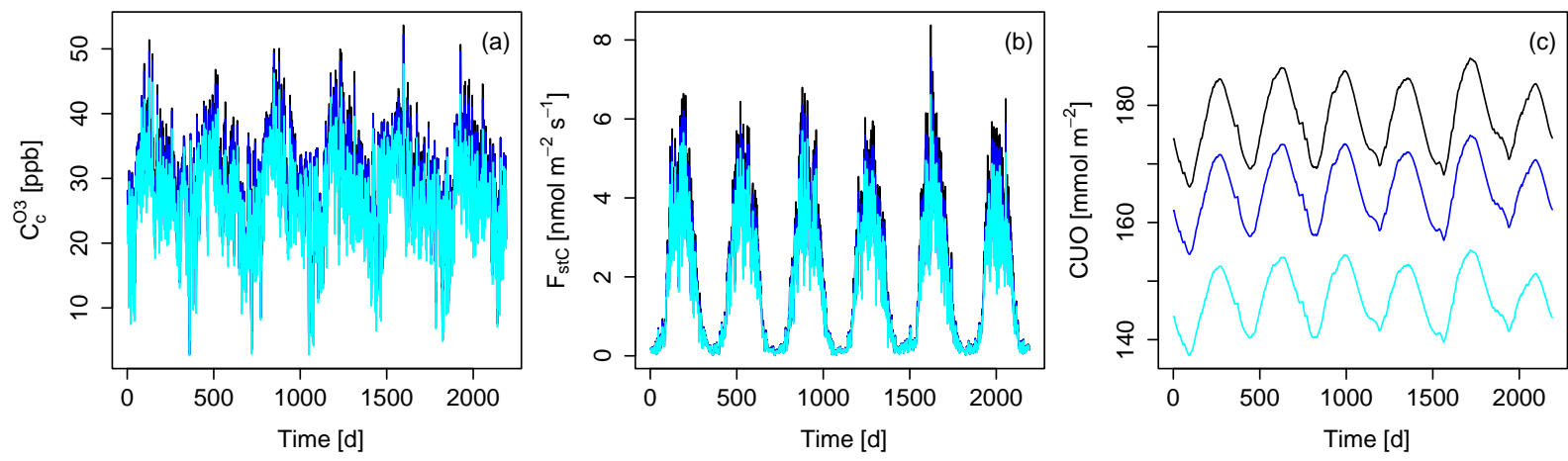

Figure 8. Mean daily values of the (a) $\mathrm{O}_{3}$ surface concentration (ppb), (b) canopy-integrated $\mathrm{O}_{3}$ uptake into the leaves $\left(\mathrm{nmol} \mathrm{m}^{-2} \mathrm{~s}^{-1}\right.$ ), and (c) canopy-integrated cumulative uptake of $\mathrm{O}_{3}(\mathrm{CUO})\left(\mathrm{mmolm}^{-2}\right)$ at the FLUXNET site FI-Hyy. Black: ATM model; dark blue: D-STO model; light blue: standard deposition model (D).

mulative $\mathrm{O}_{3}$ uptake. Sitch et al. (2007) simulated global GPP reductions of $8-14 \%$ (under elevated and fixed $\mathrm{CO}_{2}$ respectively) for low plant ozone sensitivity and $15-23 \%$ (under elevated and fixed $\mathrm{CO}_{2}$ respectively) for high plant ozone sensitivity for the year 2100 compared to 1901. For the EuroMediterranean region an average GPP reduction of $22 \%$ was estimated by the ORCHIDEE model for the year 2002 using an AOT40-based approach (Anav et al., 2011).

Possible causes for the discrepancies are differences in dose-response relationships, flux thresholds accounting for the detoxification ability of the plants, atmospheric $\mathrm{O}_{3}$ concentrations, simulation periods, and simulation of climate change (elevated $\mathrm{CO}_{2}$ ) and air pollution (nitrogen deposition). We discuss the most important aspects below. To elucidate the reasons for the substantial differences in the damage estimates, further studies are necessary to disentangle the combined effects of differing flux thresholds, damage relationships, climate change, and deposition of nitrogen.

\subsection{Atmosphere-leaf transport of ozone}

The sensitivity analysis in Sect. 3.3 demonstrates that the estimate of canopy conductance $\left(G_{\mathrm{c}}\right)$ is crucial for calculating plant ozone uptake; therefore, reliable observations to 

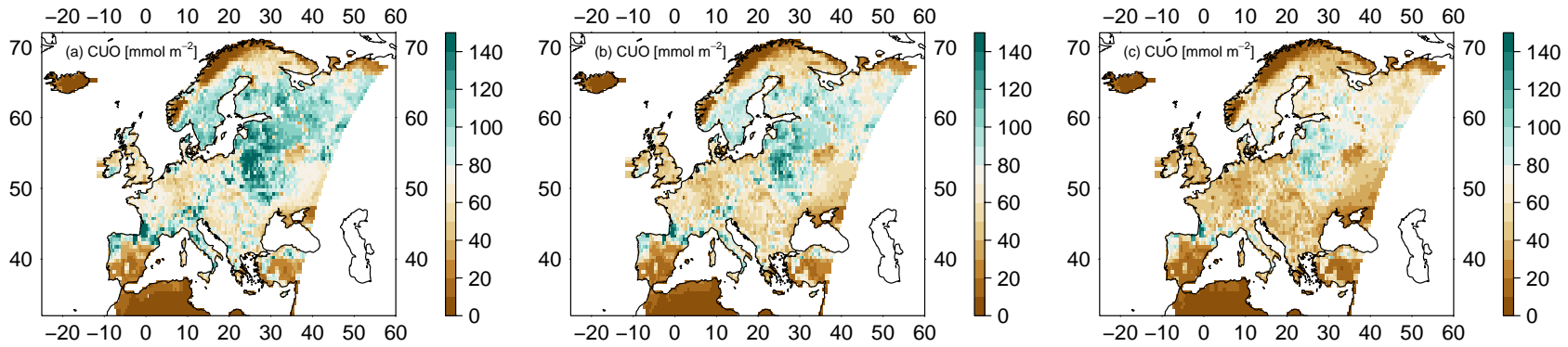

Figure 9. Mean decadal canopy-integrated cumulative uptake of $\mathrm{O}_{3}$ (CUO) $\left(\mathrm{mmolm}^{-2}\right.$ ) for Europe of the years 2001-2010. (a) Canopy $\mathrm{O}_{3}$ concentration is equal to the atmospheric concentration (ATM) and (b) $\mathrm{O}_{3}$ surface resistance is only determined by stomatal resistance (D-STO). (c) Standard ozone deposition scheme (D).

constrain modelled canopy conductance are highly important. The site-level evaluation shows that OCN produces reasonable estimates of simulated gross primary productivity (GPP), canopy conductance, and latent heat flux (LE) compared to FLUXNET observations. This agreement has to be seen in the light of the diverse set of random and systematic errors in the eddy-covariance measurements as well as derived flux and conductance estimates (Richardson et al., 2012; Knauer et al., 2016). Next to uncertainties about the strength of the aerodynamic coupling between atmosphere and canopy, problems exist at many sites with respect to the energy balance closure (Wilson et al., 2002). Failure to close the energy balance can cause underestimation of sensible and latent heat, as well as an overestimation of available energy, with mean bias of $20 \%$ where the imbalance is greatest during nocturnal periods (Wilson et al., 2002). This imbalance propagates to estimates of canopy conductance, which is inferred from latent and sensible heat fluxes. The energy imbalance furthermore appears to affect estimates of $\mathrm{CO}_{2}$ uptake and respiration (Wilson et al., 2002). Flux partitioning algorithms which extrapolate night-time ecosystem respiration estimates to daytime introduce an additional potential for bias in the estimation of GPP (Reichstein et al., 2005). Nevertheless, the general good agreement of $G_{\mathrm{c}}$ compared to FLUXNET estimates, together with the finding that modelled values of key ozone variables are within observed ranges, supports the use of the extended OCN model for determining the effect of air pollution on terrestrial carbon, nitrogen, and water cycling.

A key difference from previous studies is our use of the use of the ozone deposition scheme, which reduces $\mathrm{O}_{3}$ surface concentrations and hence also the estimated $\mathrm{O}_{3}$ uptake and accumulation (see Fig. 9). Accounting for stomatal and non-stomatal deposition in the calculation of the surface $\mathrm{O}_{3}$ concentrations considerably impacts the estimated plant uptake of $\mathrm{O}_{3} \cdot \mathrm{O}_{3}$ uptake and cumulated uptake are considerably overestimated when atmospheric ozone concentrations are used to calculate $\mathrm{O}_{3}$ uptake or when in the calculation of leaf-level $\mathrm{O}_{3}$ concentrations only stomatal destruction of $\mathrm{O}_{3}$ is regarded (see Sect. 3.5). Compared to the values that would have been obtained if the $\mathrm{CTM} \mathrm{O}_{3}$ concentrations of the atmosphere (from ca. $45 \mathrm{~m}$ height) had been used directly at the leaf surface, our simulations yield a decrease in CUO by $31 \%$ (European means for the years 2001-2010). A significant fraction of the decreases is associated with nonstomatal $\mathrm{O}_{3}$ uptake and destruction at the surface, which decreased the simulated cumulative $\mathrm{O}_{3}$ uptake by $16 \%$. To obtain an estimate of CUO that is as accurate as possible, stomatal and non-stomatal destruction of $\mathrm{O}_{3}$ and their impacts on canopy $\mathrm{O}_{3}$ concentrations should be accounted for in terrestrial biosphere models (Tuovinen et al., 2009). Fluxbased ozone damage assessment models may overestimate ozone-related damage unless they properly account for nonstomatal $\mathrm{O}_{3}$ uptake at the surface.

We note that vegetation type and dynamics also impact the stomatal and non-stomatal deposition of $\mathrm{O}_{3}$, and hence the calculation of the leaf-level $\mathrm{O}_{3}$ concentrations. This impedes the use of CTM-derived leaf-level $\mathrm{O}_{3}$ concentration, as CTM and vegetation specifications may differ strongly. Using the $\mathrm{O}_{3}$ from the lowest level of the atmosphere reduces this problem, but running a terrestrial biosphere with a fixed atmospheric boundary condition (and not coupled to a atmospheric CTM) is still a simplification that prevents biosphere-atmosphere feedbacks and therefore to potential discrepancies between vegetation and CTM. Not accounting for this feedback and stomatal and non-stomatal $\mathrm{O}_{3}$ deposition might result in an overestimation of $\mathrm{O}_{3}$ uptake and hence potential damage in the vegetation model. The deposition scheme in OCN offers the potential to couple vegetation and chemical transport modelling and is thus a step forward towards coupled atmosphere-vegetation simulations.

\subsection{Estimating vegetation damage from ozone uptake}

A key aspect of ozone damage estimates are the assumed dose-response relationships, which relate $\mathrm{O}_{3}$ uptake to plant damage. The use of flux-based relationships is generally thought to improve damage estimates compared to concentration-based metrics (e.g. AOT40), since stomatal constraints on $\mathrm{O}_{3}$ uptake are taken into account, yielding 
very different spatial patterns of exposure hotspots (Simpson et al., 2007). Similar to Simpson et al. (2007), we find strongly differing patterns between cumulative $\mathrm{O}_{3}$ uptake (CUO) and AOT40 in our simulations here (see Fig. 6), where highest exposure is found not only in southern Europe, where the $\mathrm{O}_{3}$ concentration is highest, but also in eastern Europe.

Several dose-response relationships exist for biomass or yield damage (see LRTAP Convention, 2010, for an overview), there are few estimates of the likely cause of this damage, i.e. the reduction in net photosynthesis. In this study, the damage relationship to net photosynthesis proposed by Wittig et al. (2007) is used. The major advantage of this relationship is that it has been obtained by meta-analysis of many different tree species and thus might indicate an average response. This relationship is therefore used for all modelled PFTs. However, a substantial disadvantage is that the meta-analysis implies a damage of $6.16 \%$ at zero accumulated $\mathrm{O}_{3}$ uptake with a rather minor increase in damage with increasing $\mathrm{O}_{3}$ uptake. This might be an important factor explaining the lower ozone damage estimates of OCN compared to other terrestrial biosphere models. In Lombardozzi et al. (2015) also a damage relationship derived from a meta-analysis is used; however, the disadvantage of predicted ozone damage at zero accumulated $\mathrm{O}_{3}$ uptake there is even greater compared to Wittig et al. (2007). Two out of three modelled PFTs assume -12.5 and $-16.1 \%$ ozone damage at zero accumulated $\mathrm{O}_{3}$ uptake (broadleaved and needle-leaved species respectively) and the third PFT (grass and crop) assumes $19.8 \%$ at zero accumulated $\mathrm{O}_{3}$ uptake together with a small increase in damage with increasing $\mathrm{O}_{3}$ uptake (Lombardozzi et al., 2015). An evaluation of the different proposed damage functions implemented in terrestrial biosphere models (e.g. Wittig et al., 2007; Lombardozzi et al., 2015; Sitch et al., 2007) is necessary to elucidate which are able to reproduce, for example, observed patterns of biomass damage and hence might be suitable to predict regional or global damage estimates. Furthermore, new damage relationships for different plant groups would be desirable for use in dynamic vegetation models to improve the ozone damage estimates, for example by ensuring an intercept close to one (zero damage at zero accumulated $O_{3}$ ).

The use of a (possibly PFT-specific) flux threshold and its magnitude naturally also impacts the CUOY (canopy cumulative $\mathrm{O}_{3}$ uptake above a threshold of $Y \mathrm{nmol} \mathrm{m}^{-2} \mathrm{~s}^{-1}$ ) and possible damage estimates (Tuovinen et al., 2007). The included damage function (Wittig et al., 2007) is designed for the CUO without a flux threshold $(Y=0)$. The impacts of using different flux thresholds on regional estimates of $\mathrm{O}_{3}$ uptake, accumulation, and damage are still poorly understood and need further research.

It should be noted that using plant $\mathrm{O}_{3}$ uptake based on leaf-level $\mathrm{O}_{3}$ concentrations, as done here, together with empirical ozone damage functions, where $\mathrm{O}_{3}$ uptake is calculated from atmospheric $\mathrm{O}_{3}$ concentrations, introduces a dis- crepancy. The $\mathrm{O}_{3}$ uptake rates of the experiments forming the damage relationship however are calculated from mean ozone concentrations, for example, over the exposure period and the respective average stomatal conductances (Wittig et al., 2007) such that the estimated $\mathrm{O}_{3}$ uptake and cumulated uptake used to derive the damage relationship are coarse approximations and underlie considerable uncertainty. The error introduced in $\mathrm{OCN}$ by using leaf-level $\mathrm{O}_{3}$ concentrations instead of atmospheric concentrations seems small, especially since the use of the leaf-level $\mathrm{O}_{3}$ concentration is the physiologically more appropriate approach.

In the current version of OCN only ozone damage to net photosynthesis is accounted for. Other processes like detoxification of $\mathrm{O}_{3}$ and injury repair (Wieser and Matyssek, 2007; Ainsworth et al., 2012), stomatal sluggishness (Paoletti and Grulke, 2010), and early senescence (Gielen et al., 2007; Ainsworth et al., 2012) are not accounted for. Decoupling of photosynthesis and stomatal conductance (e.g. through stomatal sluggishness) might impact GPP and transpiration damage estimates and requires further analysis. Accounting for direct impairment of the stomata might reduce the reported reductions in transpiration or even cause an increase compared to simulations with no ozone damage. Reduced carbon gain due to early senescence might impact the growth and biomass accumulation of plants (Gielen et al., 2007; Ainsworth et al., 2012) and ought to also be included in terrestrial biosphere models.

\section{Conclusions}

Estimates of $\mathrm{O}_{3}$ impacts on plant gross primary productivity vary substantially. This uncertainty in the magnitude of damage and hence the potential impact on the global carbon budget is related to different approaches to model ozone damage. The use of a comparatively detailed ozone deposition scheme that accounts for non-stomatal as well as stomatal deposition when calculating surface $\mathrm{O}_{3}$ concentrations substantially affects $\mathrm{O}_{3}$ uptake in our model. We therefore recommend that non-stomatal $\mathrm{O}_{3}$ uptake be routinely included in model assessments of ozone damage to obtain a better estimate of ozone uptake and accumulation. We show that $\mathrm{O}_{3}$ uptake into the stomata is mainly determined by the canopy conductance in the ozone deposition scheme used here. This highlights the importance of reliable modelling of canopy conductances as well as realistic surface $\mathrm{O}_{3}$ concentrations to obtain as accurate as possible estimates of $\mathrm{O}_{3}$ uptake, which are the basis for plant damage estimates. Suitable ozone damage relationships to net photosynthesis for different plant groups are essential to relate the accumulated $\mathrm{O}_{3}$ uptake to plant damage in a model. Mean responses of plant groups similar to commonly modelled PFTs are also desirable. Only a few damage relationships exist, which indicate mean responses of several species (e.g. Wittig et al., 2007; Lombardozzi et al., 2013, which, however, propose very different relationships). 
Furthermore, the impact of the plants ability to detoxify $\mathrm{O}_{3}$ should be considered by using, for example, flux thresholds, as well as the combined effects of $\mathrm{O}_{3}$ with air pollution (nitrogen deposition) and climate change (elevated $\mathrm{CO}_{2}$ ) on the plants' carbon uptake.

\section{Data availability}

No original measurements were used. The FLUXNET measurements can be accessed from the La Thuile Dataset (http: //fluxnet.fluxdata.org/data/la-thuile-dataset/). 


\section{Appendix A: Aerodynamic resistance}

To calculate the $\mathrm{O}_{3}$ deposition of the free atmosphere at the lowest level of the CTM (approximately $45 \mathrm{~m}$ ) to the vegetation canopy, it is necessary to know the aerodynamic resistance between these heights $\left(R_{\mathrm{a}, 45}\right)$. These data are modeland land-cover-specific, and thus not provided by the CTM. Instead, we approximate $R_{\mathrm{a}, 45}$ from the wind speed at $45 \mathrm{~m}$ height $\left(u_{45}\right)$ and the friction velocity $u_{*}$ according to

$$
R_{a, 45}=\frac{u_{45}}{u_{*}^{2}},
$$

where $u_{*}$ is calculated from the wind speed at $10 \mathrm{~m}$ height $\left(u_{10}\right)$ using the atmospheric resistance calculations of the ORCHIDEE model (Krinner et al., 2005). The wind at $45 \mathrm{~m}$ $\left(u_{45}\right)$ is approximated by assuming the logarithmic wind profile for neutral atmospheric conditions (Monteith and Unsworth, 2007) due to the lack of information on any other relevant atmospheric properties at $45 \mathrm{~m}$ height:

$u_{45}=u_{10} \frac{\log \left(\frac{45}{z_{0}}\right)}{\log \left(\frac{10}{z_{0}}\right)}$,

where $z_{0}$ is the roughness length.

eaves depending on surface conditions and vegetation carbon uptake.

\section{Appendix B: Emissions inventory}

Emissions for the EMEP model were derived by merging data from three main sources. Firstly, emissions for 2005 and 2010 were taken from the ECLIPSE database produced by IIASA for various EU Projects and the Task Force on Hemispheric Transport of Air Pollution (Amann et al., 2013; Stohl et al., 2015), although with improved spatial resolution over Europe by making use of the $7 \mathrm{~km}$ resolution MACC- 2 emissions produced by TNO (Kuenen et al., 2014). For 1990, emissions from land-based sources were taken directly from the EMEP database for that year, since 1990 had been the subject of recent review and quality control (e.g. Mareckova et al., 2013). Emissions between 1990 and 2005 were estimated via linear interpolation between these 2005 and EMEP 1990 values. Emissions prior to 1990 were derived by scaling the EMEP 1990 emissions by the emissions ratios found in the historical data series of Lamarque et al. (2010).

Emissions of the biogenic hydrocarbon isoprene from vegetation are calculated using the model's land cover and meteorological data (Simpson et al., 2012, 1999). Emissions of NO from biogenic sources (soils, forest fires, etc.) were set to zero given both their uncertainty and sporadic occurrence. Tests have shown that this approximation has only a small impact on annual deposition totals to the EU area, even for simulations at the start of the 20th century. Volcanic emissions of sulfur dioxide $\left(\mathrm{SO}_{2}\right)$ were set to a constant value from the year 2010 . 
Table A1. Characteristics of the FLUXNET sites used in this study.

\begin{tabular}{|c|c|c|c|c|c|c|}
\hline Sites & Latitude & Longitude & Climate $^{\mathrm{a}}$ & $\mathrm{PFT}^{\mathrm{b}}$ & Years & Reference \\
\hline AT-Neu & 47.12 & 11.32 & $\mathrm{Cfb}$ & $\mathrm{TeH}$ & $2002-2005$ & Wohlfahrt et al. (2008b) \\
\hline $\mathrm{CH}-\mathrm{Oe} 1$ & 47.29 & 7.73 & $\mathrm{Cfb}$ & $\mathrm{TeH}$ & $2002-2006$ & Ammann et al. (2007) \\
\hline DE-Bay & 50.14 & 11.87 & $\mathrm{Cfb}$ & $\mathrm{CEF}$ & 1997-1998 & Rebmann et al. (2004) \\
\hline DE-Hai & 51.08 & 10.45 & $\mathrm{Cfb}$ & TeBDF & 2000-2006 & Kutsch et al. (2008) \\
\hline DE-Meh & 51.28 & 10.66 & $\mathrm{Cfb}$ & $\mathrm{TeH}$ & 2004-2006 & Scherer-Lorenzen et al. (2007) \\
\hline DE-Tha & 50.96 & 13.57 & $\mathrm{Cfb}$ & $\mathrm{CEF}$ & 2004-2006 & Grünwald and Bernhofer (2007) \\
\hline DK-Lva & 55.68 & 12.08 & $\mathrm{Cfb}$ & $\mathrm{TeH}$ & 2005-2006 & Gilmanov et al. (2007) \\
\hline DK-Sor & 55.49 & 11.65 & $\mathrm{Cfb}$ & TeBDF & 1997-2006 & Lagergren et al. (2008) \\
\hline ES-ES1 & 39.35 & -0.32 & Csa & $\mathrm{CEF}$ & 1999-2004 & Sanz et al. (2004) \\
\hline FI-Hyy & 61.85 & 24.29 & Dfc & $\mathrm{CEF}$ & 2001-2006 & Suni et al. (2003) \\
\hline FR-Hes & 48.67 & 7.06 & $\mathrm{Cfb}$ & TeBDF & 2001-2006 & Granier et al. (2000) \\
\hline FR-LBr & 44.72 & -0.77 & $\mathrm{Cfb}$ & $\mathrm{CEF}$ & 2003-2006 & Berbigier et al. (2001) \\
\hline FR-Pue & 43.74 & 3.60 & Csa & TeBEF & 2001-2006 & Keenan et al. (2010) \\
\hline IL-Yat & 31.34 & 35.05 & BSh & $\mathrm{CEF}$ & 2001-2002 & Grünzweig et al. (2003) \\
\hline IT-Cpz & 41.71 & 12.38 & Csa & TeBEF & 2001-2006 & Tirone et al. (2003) \\
\hline IT-Lav & 45.96 & 11.28 & $\mathrm{Cfb}$ & $\mathrm{CEF}$ & 2006-2006 & Marcolla et al. (2003) \\
\hline IT-MBo & 46.02 & 11.05 & $\mathrm{Cfb}$ & $\mathrm{TeH}$ & 2003-2006 & Wohlfahrt et al. (2008a) \\
\hline IT-PT1 & 45.20 & 9.06 & $\mathrm{Cfa}$ & TeBDF & 2003-2004 & Migliavacca et al. (2009) \\
\hline IT-Ro1 & 42.41 & 11.93 & Csa & TeBDF & 2002-2006 & Rey et al. (2002) \\
\hline IT-Ro2 & 42.39 & 11.92 & Csa & TeBDF & 2002-2006 & Tedeschi et al. (2006) \\
\hline IT-SRo & 43.73 & 10.28 & Csa & $\mathrm{CEF}$ & 2003-2006 & Chiesi et al. (2005) \\
\hline NL-Loo & 52.17 & 5.74 & $\mathrm{Cfb}$ & $\mathrm{CEF}$ & 1997-2006 & Dolman et al. (2002) \\
\hline PT-Esp & 38.64 & -8.60 & Csa & TeBEF & 2002-2006 & Pereira et al. (2007) \\
\hline PT-Mi1 & 38.54 & -8.00 & Csa & $\mathrm{TeS}$ & 2003-2005 & Pereira et al. (2007) \\
\hline SE-Fla & 64.11 & 19.46 & Dfc & $\mathrm{CEF}$ & 2000-2002 & Lindroth et al. (2008) \\
\hline SE-Nor & 60.09 & 17.48 & Dfb & $\mathrm{CEF}$ & 1996-1997 & Lagergren et al. (2008) \\
\hline
\end{tabular}

a Köppen-Geiger climate zone (BSh: hot arid steppe; Cfa: humid, warm temperate, hot summer; Cfb: humid, warm temperate, warm summer; Csa: summer dry, warm temperate, hot summer; Dfb: cold, humid, warm summer; Dfc: cold, humid, cold summer). ${ }^{\mathrm{b}}$ Plant functional type (TeBEF: temperate broadleaf evergreen forest; TeBDF: temperate broadleaf deciduous forest; CEF: coniferous evergreen forest; TeS: temperate open woodland with $\mathrm{C}_{3}$ grass; $\mathrm{TeH}: \mathrm{C}_{3}$ grassland).

Table A2. Coefficient of determination $\left(R^{2}\right)$ and root mean square error (RMSE) for GPP, canopy conductance $\left(G_{\mathrm{c}}\right)$, and latent heat flux (LE) for all sites and for sites dominated by broadleaved trees, needle-leaved trees, $\mathrm{C}_{3}$ grass, and $\mathrm{C}_{3}$ grass excluding the AT-Neu site (outlier).

\begin{tabular}{llrrrr}
\hline & All sites & Broadleaved & Needle-leaved & $\mathrm{C}_{3}$ grass & $\begin{array}{r}\mathrm{C}_{3} \text { grass } \\
\text { (excluding AT-Neu) }\end{array}$ \\
\hline$R^{2}:$ GPP & 0.465 & 0.714 & 0.8 & 0.139 & 0.058 \\
RMSE: GPP & 3.495 & 3.771 & 1.944 & 5.175 & 2.257 \\
$R^{2}: G_{\mathrm{c}}$ & 0.458 & 0.69 & 0.722 & 0.013 & 0.01 \\
RMSE: $G_{\mathrm{c}}$ & 0.001 & 0.002 & 0.001 & 0.002 & 0.002 \\
$R^{2}:$ LE & 0.566 & 0.725 & 0.9 & 0.022 & 0.002 \\
RMSE: LE & 30.897 & 39.725 & 13.977 & 37.124 & 40.493 \\
\hline
\end{tabular}



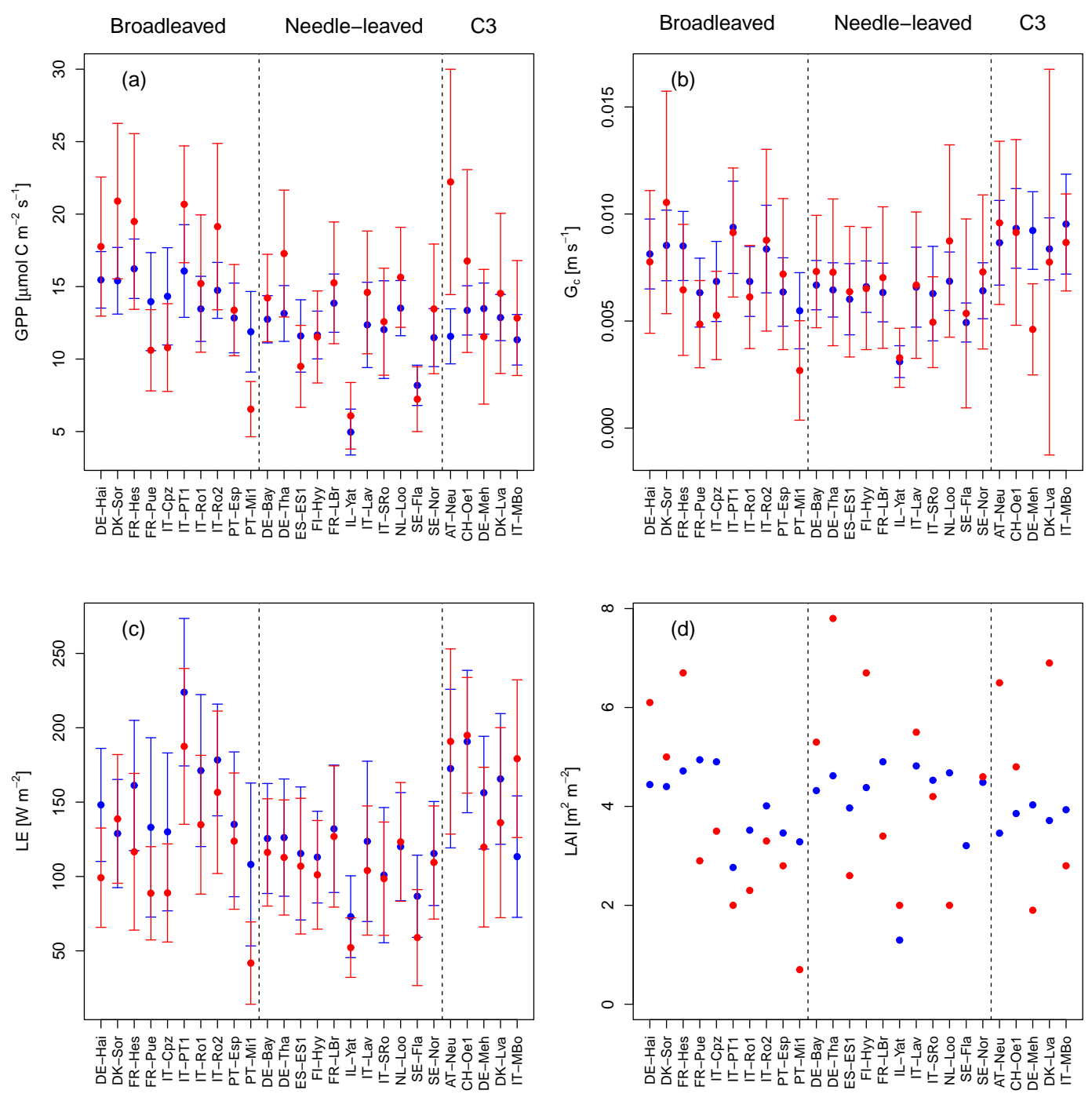

Figure A1. Comparison of measured (a) GPP, (b) $G_{\mathrm{c}}$, (c) latent heat flux (LE), and (d) LAI at 26 European FLUXNET sites (red) and simulations by OCN (blue). Displayed are means and standard deviation of daily means of the measuring/simulation period, with the exceptions of FLUXNET-derived LAI, which is based on point measurements. 
(a) Broadleaved trees
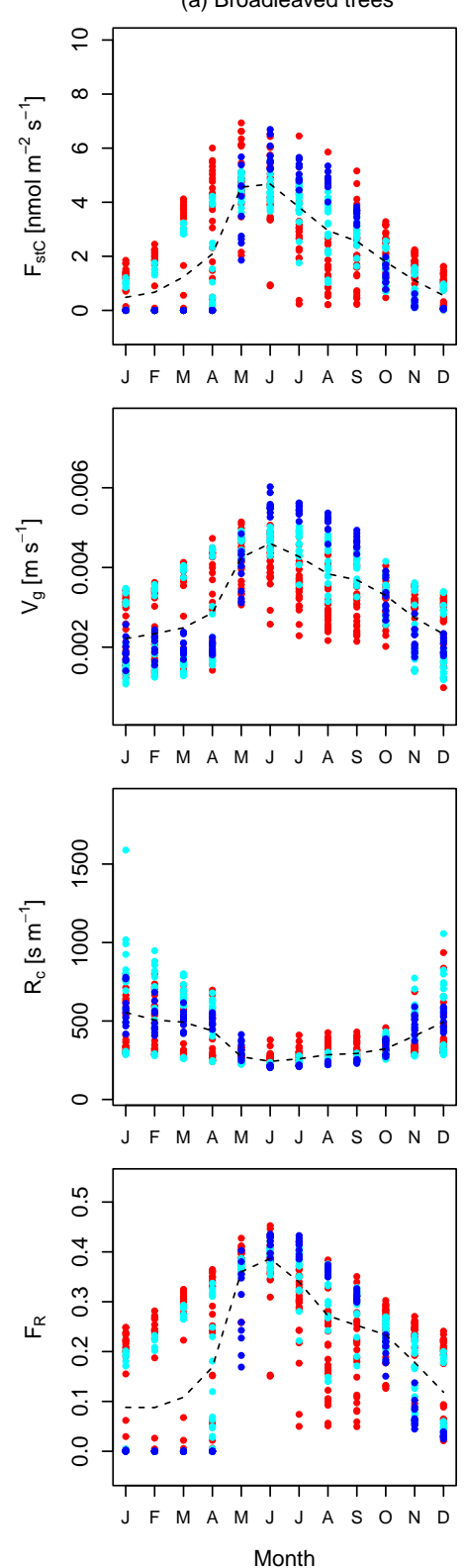

(b) Needle-leaved trees
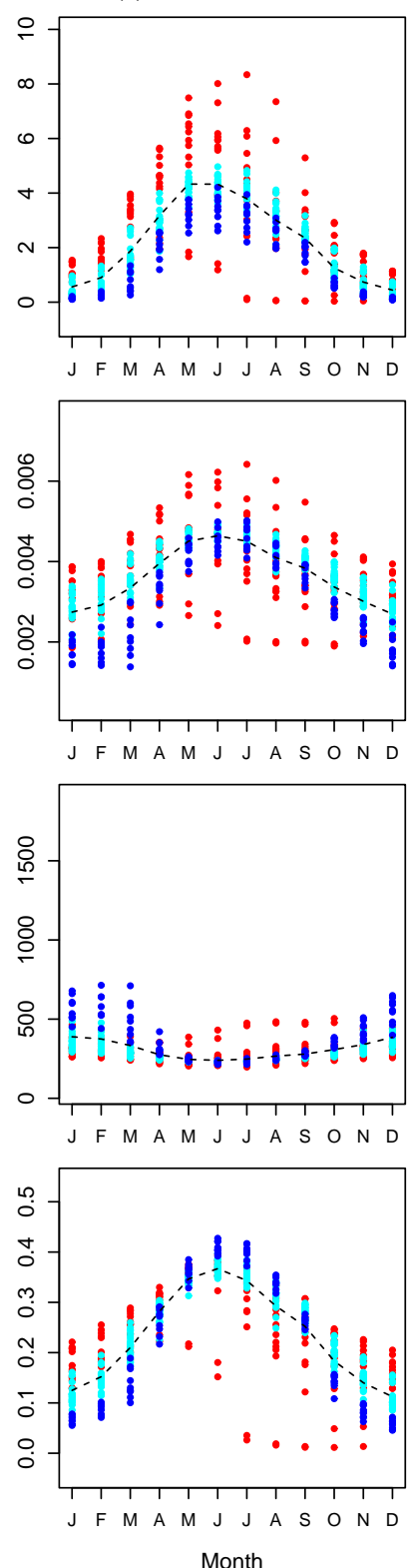

(c) C3 grasses
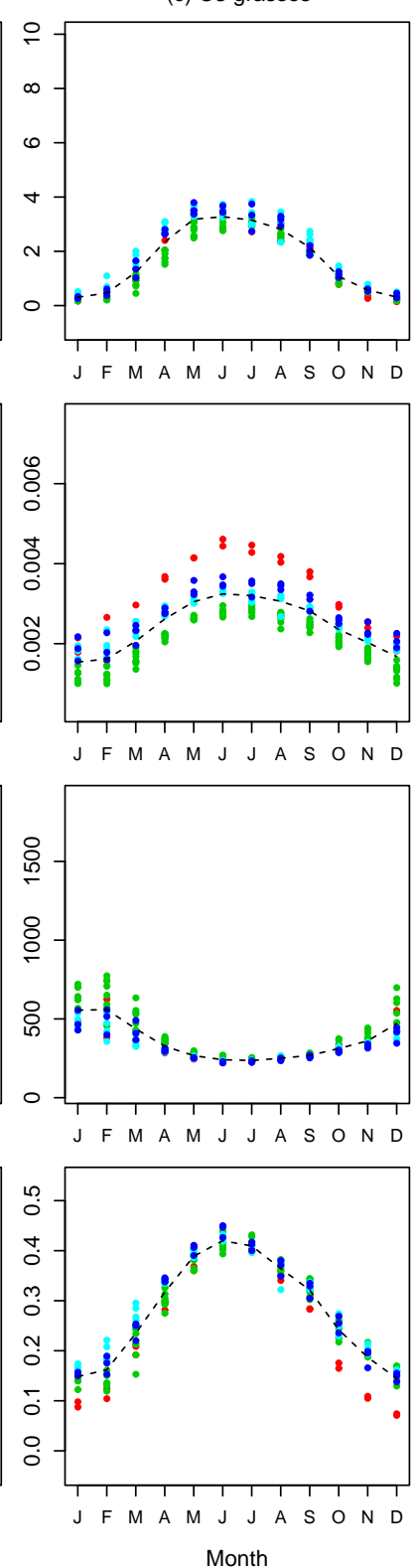

Figure A2. Simulated monthly mean values of $\mathrm{O}_{3}$ uptake $\left(F_{\mathrm{stC}}\right), \mathrm{O}_{3}$ deposition velocity $\left(V_{\mathrm{g}}\right), \mathrm{O}_{3}$ surface resistance $\left(R_{\mathrm{c}}\right)$, and the flux ratio $\left(F_{\mathrm{R}}\right)$ for sites dominated by broadleaved trees (left column), needle-leaved trees (central column), and $\mathrm{C}_{3}$ grasses (right column). The colour indicates the location of the site. Dark blue: Denmark, Sweden, and Finland; light blue: Germany, France, and Netherlands; green: Austria and Switzerland; red: Italy, Portugal, Spain, and Israel. Broken line: mean of all sites and years of the 12 months. 

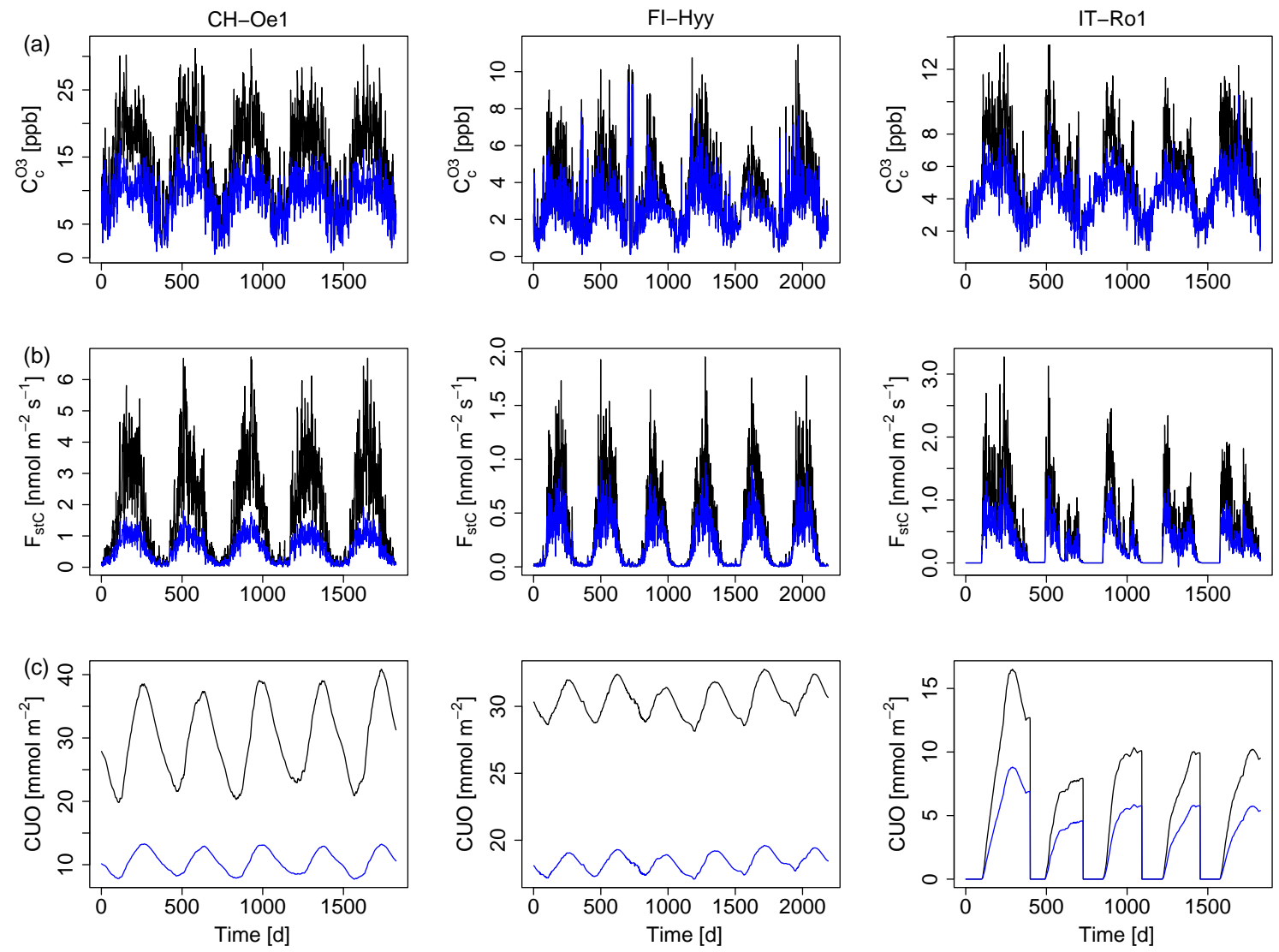

Figure A3. Differences in mean daily values of the (a) $\mathrm{O}_{3}$ surface concentration (ppb), (b) canopy-integrated $\mathrm{O}_{3}$ uptake into the leaves $\left(\right.$ nmol m$\left.{ }^{-2} \mathrm{~s}^{-1}\right)$, and (c) canopy-integrated cumulative uptake of $\mathrm{O}_{3}$ (CUO) (mmol m${ }^{-2}$ ) for the three FLUXNET sites CH-Oe1, FI-Hyy and IT-Ro1. Blue: difference between the D-STO model and the standard model (D); black: difference between the ATM model and the standard model (D). 
Acknowledgements. We would like to thank Magnuz Engardt of the Swedish Meteorological and Hydrological Institute for providing the RCA3 climate dataset. The research leading to this publication was supported by the EU Framework Programme through grant no. 282910 (ECLAIRE), as well as the Max Planck Society for the Advancement of Science e.V. through the ENIGMA project. This project received funding from the European Research Council (ERC) under the European Union's Horizon 2020 research and innovation programme (grant agreement no. 647204; QUINCY). Computer time for EMEP model runs was supported by the Research Council of Norway (Programme for Supercomputing).

Edited by: A. V. Eliseev

Reviewed by: F. Dentener and one anonymous referee

\section{References}

Ainsworth, E. A., Yendrek, C. R., Sitch, S., Collins, W. J., and Emberson, L. D.: The Effects of Tropospheric Ozone on Net Primary Productivity and Implications for Climate Change, Ann. Rev. Plant Biol., 63, 637-661, 2012.

Amann, M., Klimont, Z., and Wagner, F.: Regional and Global Emissions of Air Pollutants: Recent Trends and Future Scenarios, Ann. Rev. Env. Res., 38, 31-55, doi:10.1146/annurevenviron-052912-173303, 2013.

Ammann, C., Flechard, C., Leifeld, J., Neftel, A., and Fuhrer, J.: The carbon budget of newly established temperate grassland depends on management intensity, Agr. Ecosys. Environ., 121, 520, 2007.

Anav, A., Menut, L., Khvorostyanov, D., and Viovy, N.: Impact of tropospheric ozone on the Euro-Mediterranean vegetation, Glob. Change Biol., 17, 2342-2359, 2011.

Arneth, A., Harrison, S. P., Zaehle, S., Tsigaridis, K., Menon, S., Bartlein, P. J., Feichter, J., Korhola, A., Kulmala, M., O’Donnell, D., Schurgers, G., Sorvari, S., and Vesala, T.: Terrestrial biogeochemical feedbacks in the climate system, Nat. Geosci., 3, 525532, doi:10.1038/ngeo905, 2010.

Baldocchi, D., Falge, E., Gu, L., Olson, R., Hollinger, D., Running, S., Anthoni, P., Bernhofer, C., Davis, K., Evans, R., Fuentes, J., Goldstein, A., Katul, G., Law, B., Lee, X., Malhi, Y., Meyers, T., Munger, W., Oechel, W., and Paw, U. K.: FLUXNET: A new tool to study the temporal and spatial variability of ecosystem-scale carbon dioxide, water vapor, and energy flux densities, Bull. Am. Meteorol. Soc., 82, 2415-2434, 2001.

Berbigier, P., Bonnefond, J.-M., and Mellmann, P.: $\mathrm{CO}_{2}$ and water vapour fluxes for 2 years above Euroflux forest site, Agr. Forest Meteorol., 108, 183-197, 2001.

Chiesi, M., Maselli, F., Bindi, M., Fibbi, L., Cherubini, P., Arlotta, E., Tirone, G., Matteucci, G., and Seufert, G.: Modelling carbon budget of Mediterranean forests using ground and remote sensing measurements, Agr. Forest Meteorol., 135, 22-34, 2005.

Cieslik, S. A.: Ozone uptake by various surface types: a comparison between dose and exposure, Atmos. Environ., 38, 2409-2420, 2004.

Cooper, O. R., Parrish, D., Ziemke, J., Balashov, N., Cupeiro, M., Galbally, I., Gilge, S., Horowitz, L., Jensen, N., Lamarque, J.-F., Naik, V., Oltmans, S., Schwab, J., Shindell, D., Thompson, A., Thouret, V., Wang, Y., and Zbinden, R.: Global distribution and trends of tropospheric ozone: An observation-based review, Elementa, 2, 000029, doi:10.12952/journal.elementa.000029, 2014.

Coyle, M., Nemitz, E., Storeton-West, R., Fowler, D., and Cape, J. N.: Measurements of ozone deposition to a potato canopy, Agr. Forest Meteorol., 149, 655-666, 2009.

Dolman, A., Moors, E., and Elbers, J.: The carbon uptake of a mid latitude pine forest growing on sandy soil, Agr. Forest Meteorol., 111, 157-170, 2002.

Ducoudré, N. I., Laval, K., and Perrier, A.: SECHIBA, a new set of parameterizations of the hydrologic exchanges at the landatmosphere interface within the LMD atmospheric general circulation model, J. Clim., 6, 248-273, 1993.

Emberson, L., Ashmore, M., Cambridge, H., Simpson, D., and Tuovinen, J.: Modelling stomatal ozone flux across Europe, Environ. Pollut., 109, 403-413, 2000.

Emberson, L., Ashmore, M., Simpson, D., Tuovinen, J.-P., and Cambridge, H.: Modelling and mapping ozone deposition in Europe, Water Air Soil Pollut., 130, 577-582, 2001.

Engardt, M., Simpson, D., and Granat, L.: Historical and projected (1900 to 2050) deposition of sulphur and nitrogen in Europe, submitted, 2017.

Felzer, B., Kicklighter, D., Melillo, J., Wang, C., Zhuang, Q., and Prinn, R.: Effects of ozone on net primary production and carbon sequestration in the conterminous United States using a biogeochemistry model, Tellus B, 56, 230-248, 2004.

Felzer, B., Reilly, J., Melillo, J., Kicklighter, D., Sarofim, M., Wang, C., Prinn, R., and Zhuang, Q.: Future effects of ozone on carbon sequestration and climate change policy using a global biogeochemical model, Climatic Change, 73, 345-373, 2005.

Fiore, A., Dentener, F., Wild, O., Cuvelier, C., Schultz, M., Textor, C., Schulz, M., Atherton, C., Bergmann, D., Bey, I., Carmichael, G., Doherty, R., Duncan, B., Faluvegi, G., Folberth, G., Garcia Vivanco, M., Gauss, M., Gong, S., Hauglustaine, D., Hess, P., Holloway, T., Horowitz, L., Isaksen, I., Jacob, D., Jonson, J., Kaminski, J., keating, T., Lupu, A., MacKenzie, I., Marmer, E., Montanaro, V., Park, R., Pringle, K., Pyle, J., Sanderson, M., Schroeder, S., Shindell, D., Stevenson, D., Szopa, S., Van Dingenen, R., Wind, P., Wojcik, G., Wu, S., Zeng, G., and Zuber, A.: Multi-model estimates of intercontinental sourcereceptor relationships for ozone pollution, J. Geophys. Res., 114, doi:10.1029/2008JD010816, doi:10.1029/2008JD010816, 2009.

Fowler, D., Pilegaard, K., Sutton, M., Ambus, P., Raivonen, M., Duyzer, J., Simpson, D., Fagerli, H., Fuzzi, S., Schjørring, J., Granieri, C., Neftel, A., Isaksen, I., Laj, P., Maione, M., Monks, P., Burkhardt, J., Daemmgen, U., Neirynck, J., Personne, E., Wichink-Kruit, R., Butterbach-Bahl, K., Flechard, C., Tuovinen, J., Coyle, M., Gerosa, G., Loubet, B., Altimir, N., Gruenhage, N., Ammann, C., Cieslik, S., Paoletti, E., Mikkelsen, T., RoPoulsen, H., Cellier, P., Cape, J., Horvath, L., Loreto, F., Niinemets, Ü., Palmer, P., Rinne, J., Misztal, P., Nemitz, E., Nilsson, D., Pryor, S., Gallagher, M., Vesala, T., Skiba, U., Brüggemann, N., and Zechmeister-Boltenstern, S.: Atmospheric composition change: ecosystems-atmosphere interactions, Atmos. Environ., 43, 5193-5267, 2009.

Friend, A. and Kiang, N.: Land surface model development for the GISS GCM: Effects of improved canopy physiology on simulated climate, J. Clim., 18, 2883-2902, 2005. 
Fusco, A. and Logan, J.: Analysis of 1970-1995 trends in tropospheric ozone at Northern Hemisphere midlatitudes with the GEOS-CHEM model, J. Geophys. Res, 108, 1988-1997, 2003.

Gerosa, G., Cieslik, S., and Ballarin-Denti, A.: Micrometeorological determination of time-integrated stomatal ozone fluxes over wheat: a case study in Northern Italy, Atmos. Environ., 37, 777788, 2003.

Gerosa, G., Marzuoli, R., Cieslik, S., and Ballarin-Denti, A.: Stomatal ozone fluxes over a barley field in Italy, "Effective exposure" as a possible link between exposure-and flux-based approaches, Atmos. Environ., 38, 2421-2432, 2004.

Gerosa, G., Vitale, M., Finco, A., Manes, F., Denti, A. B., and Cieslik, S.: Ozone uptake by an evergreen Mediterranean forest (Quercus ilex) in Italy. Part I: Micrometeorological flux measurements and flux partitioning, Atmos. Environ., 39, 3255-3266, 2005.

Gielen, B., Löw, M., Deckmyn, G., Metzger, U., Franck, F., Heerdt, C., Matyssek, R., Valcke, R., and Ceulemans, R.: Chronic ozone exposure affects leaf senescence of adult beech trees: a chlorophyll fluorescence approach, J. Experim. Bot., 58, 785-795, doi:10.1093/jxb/erl222, 2007.

Gilmanov, T., Soussana, J., Aires, L., Allard, V., Ammann, C., Balzarolo, M., Barcza, Z., Bernhofer, C., Campbell, C., Cernusca, A., Cescatti, A., Clifton-Brown, J., Dirks, B., Dore, S., Eugster, W., Fuhrer, J., Gimeno, C., Gruenwald, T., Haszpra, L., Hensen, A., Ibrom, A., Jacobs, A., Jones, M., Lanigan, G., Laurila, T., Lohila, A., Manca, G., Marcolla, B., Nagy, Z., Pilegaard, K., Pinter, K., Pio, C Raschi, A., Rogiers, N., Sanz, M., Stefani, P., Sutton, M., Tuba, Z., Valentini, R., Williams, M., and Wohlfahrt, G.: Partitioning European grassland net ecosystem $\mathrm{CO}_{2}$ exchange into gross primary productivity and ecosystem respiration using light response function analysis, Agr. Ecosys. Environ., 121, 93-120, 2007.

Granier, A., Ceschia, E., Damesin, C., Dufrêne, E., Epron, D., Gross, P., Lebaube, S., Le Dantec, V., Le Goff, N., Lemoine, D., Lucot, E., Ottorini, J., Pontailler, J., and Saugier, B.: The carbon balance of a young beech forest, Funct. Ecol., 14, 312-325, 2000.

Grünwald, T. and Bernhofer, C.: A decade of carbon, water and energy flux measurements of an old spruce forest at the Anchor Station Tharandt, Tellus B, 59, 387-396, 2007.

Grünzweig, J., Lin, T., Rotenberg, E., Schwartz, A., and Yakir, D.: Carbon sequestration in arid-land forest, Glob. Change Biol., 9, 791-799, 2003.

Hardacre, C., Wild, O., and Emberson, L.: An evaluation of ozone dry deposition in global scale chemistry climate models, Atmos. Chem. Phys., 15, 6419-6436, doi:10.5194/acp-15-64192015, 2015.

Helton, J. and Davis, F.: Illustration of sampling-based methods for uncertainty and sensitivity analysis, Risk Anal., 22, 591-622, 2002.

Jenkin, M.: Trends in ozone concentration distributions in the UK since 1990: Local, regional and global influences, Atmos. Environ., 42, 5434-5445, 2008.

Jung, M., Reichstein, M., Margolis, H., Cescatti, A., Richardson, A., Arain, M., Arneth, A., Bernhofer, C., Bonal, D., Chen, J., Gianelle, D., Gobron, N., Kiely, G., Kutsch, W., Lasslop, G., Law, B., Lindroth, A., Merbold, L., Montagnani, L., Moors, E., Papale, D., Sottocornola, M., Vaccari, F., and Williams, C.: Global patterns of land-atmosphere fluxes of carbon dioxide, la- tent heat, and sensible heat derived from eddy covariance, satellite, and meteorological observations, J. Geophys. Res.-Biogeo., 116, g00J07, doi:10.1029/2010JG001566, 2011.

Kangasjärvi, J., Talvinen, J., Utriainen, M., and Karjalainen, R.: Plant defence systems induced by ozone, Plant Cell Environ., 17, 783-794, 1994.

Keenan, T., Sabate, S., and Gracia, C.: Soil water stress and coupled photosynthesis-conductance models: Bridging the gap between conflicting reports on the relative roles of stomatal, mesophyll conductance and biochemical limitations to photosynthesis, Agr. Forest Meteorol., 150, 443-453, 2010.

Keronen, P., Reissell, A., Rannik, U., Pohja, T., Siivola, E., Hiltunen, V., Hari, P., Kulmala, M., and Vesala, T.: Ozone flux measurements over a Scots pine forest using eddy covariance method: performance evaluation and comparison with fluxprofile method, Boreal Environ. Res., 8, 425-444, 2003.

Kjellstrom, E., Nikulin, G., Hansson, U., Strandberg, G., and Ullerstig, A.: 21st century changes in the European climate: uncertainties derived from an ensemble of regional climate model simulations, Tellus A, 63, 24-40, doi:10.1111/j.16000870.2010.00475.x, 2011.

Klingberg, J., Danielsson, H., Simpson, D., and Pleijel, H.: Comparison of modelled and measured ozone concentrations and meteorology for a site in south-west Sweden: Implications for ozone uptake calculations, Environ. Poll., 115, 99-111, 2008.

Knauer, J., Werner, C., and Zaehle, S.: Evaluating stomatal models and their atmospheric drought response in a land surface scheme: A multibiome analysis, J. Geophys. Res.-Biogeo., 120, 1894 1911, 2015.

Knauer, J., Zaehle, S., Reichstein, M., Medlyn, B. E., Forkel, M., Hagemann, S., and Werner, C.: The response of ecosystem wateruse efficiency to rising atmospheric $\mathrm{CO}_{2}$ concentrations: sensitivity and large-scale biogeochemical implications, New Phytol., 2016-22438,, doi:10.1111/nph.14288, 2016.

Krinner, G., Viovy, N., de Noblet-Ducoudré, N., Ogée, J., Polcher, J., Friedlingstein, P., Ciais, P., Sitch, S., and Prentice, I.: A dynamic global vegetation model for studies of the coupled atmosphere-biosphere system, Global Biogeochem. Cy., 19, GB1015, doi:10.1029/2003GB002199, 2005.

Kronfuß, G., Polle, A., Tausz, M., Havranek, W., and Wieser, G.: Effects of ozone and mild drought stress on gas exchange, antioxidants and chloroplast pigments in current-year needles of young Norway spruce (Picea abies (L.) Karst.), Trees-Struct. Funct., 12, 482-489, 1998.

Kuenen, J., Denier van der Gon, H., Visschedijk, A., van der Brugh, H., and van Gijlswijk, R.: MACC European emission inventory for the years 2003-2007, TNO Report TNO-060-UT-201100588, TNO, Utrecht, the Netherlands, www.tno.nl, 2011.

Kuenen, J., Visschedijk, A., Jozwicka, M., and Denier van der Gon, H.: TNO-MACC_II emission inventory; a multi-year (20032009) consistent high-resolution European emission inventory for air quality modelling, Atmos. Chem. Phys., 14, 10963, doi:10.5194/acp-14-10963-2014, 2014.

Kutsch, W. L., Kolle, O., Rebmann, C., Knohl, A., Ziegler, W., and Schulze, E.-D.: Advection and resulting $\mathrm{CO}_{2}$ exchange uncertainty in a tall forest in central Germany, Ecol. Appl., 18, 13911405, 2008.

Lagergren, F., Lindroth, A., Dellwik, E., Ibrom, A., Lankreijer, H., Launiainen, S., Mölder, M., Kolari, P., Pilegaard, K., and Vesala, 
T.: Biophysical controls on $\mathrm{CO}_{2}$ fluxes of three northern forests based on long-term eddy covariance data, Tellus B, 60, 143-152, 2008.

Laisk, A., Kull, O., and Moldau, H.: Ozone concentration in leaf intercellular air spaces is close to zero, Plant Physiol., 90, 11631167, 1989.

Lamarque, J. F., Bond, T. C., Eyring, V., Granier, C., Heil, A., Klimont, Z., Lee, D., Liousse, C., Mieville, A., Owen, B., Schultz, M. G., Shindell, D., Smith, S. J., Stehfest, E., Van Aardenne, J., Cooper, O. R., Kainuma, M., Mahowald, N., McConnell, J. R., Naik, V., Riahi, K., and van Vuuren, D. P.: Historical (1850-2000) gridded anthropogenic and biomass burning emissions of reactive gases and aerosols: methodology and application, Atmos. Chem. Physics, 10, 7017-7039, doi:10.5194/acp10-7017-2010, 2010.

Le Quéré, C., Moriarty, R., Andrew, R. M., Peters, G. P., Ciais, P., Friedlingstein, P., Jones, S. D., Sitch, S., Tans, P., Arneth, A., Boden, T. A., Bopp, L., Bozec, Y., Canadell, J. G., Chini, L. P., Chevallier, F., Cosca, C. E., Harris, I., Hoppema, M., Houghton, R. A., House, J. I., Jain, A. K., Johannessen, T., Kato, E., Keeling, R. F., Kitidis, V., Klein Goldewijk, K., Koven, C., Landa, C. S., Landschützer, P., Lenton, A., Lima, I. D., Marland, G., Mathis, J. T., Metzl, N., Nojiri, Y., Olsen, A., Ono, T., Peng, S., Peters, W., Pfeil, B., Poulter, B., Raupach, M. R., Regnier, P., Rödenbeck, C., Saito, S., Salisbury, J. E., Schuster, U., Schwinger, J., Séférian, R., Segschneider, J., Steinhoff, T., Stocker, B. D., Sutton, A. J., Takahashi, T., Tilbrook, B., van der Werf, G. R., Viovy, N., Wang, Y.-P., Wanninkhof, R., Wiltshire, A., and Zeng, N.: Global carbon budget 2014, Earth Syst. Sci. Data, 7, 47-85, doi:10.5194/essd-7-47-2015, 2015.

Lindroth, A., Klemedtsson, L., Grelle, A., Weslien, P., and Langvall, O.: Measurement of net ecosystem exchange, productivity and respiration in three spruce forests in Sweden shows unexpectedly large soil carbon losses, Biogeochemistry, 89, 43-60, 2008.

Lombardozzi, D., Sparks, J. P., and Bonan, G.: Integrating $\mathrm{O}_{3}$ influences on terrestrial processes: photosynthetic and stomatal response data available for regional and global modeling, Biogeosciences, 10, 6815-6831, doi:10.5194/bg-10-6815-2013, 2013.

Lombardozzi, D., Levis, S., Bonan, G., Hess, P., and Sparks, J.: The Influence of Chronic Ozone Exposure on Global Carbon and Water Cycles, J. Clim., 28, 292-305, 2015.

LRTAP Convention: Manual on Methodologies and Criteria for Modelling and Mapping Critical Loads and Levels; and Air Pollution Effects, Risks and Trends, http://www.rivm.nl/en/ themasites/icpmm/index.html, 2010.

Luwe, M. and Heber, U.: Ozone detoxification in the apoplasm and symplasm of spinach, broad bean and beech leaves at ambient and elevated concentrations of ozone in air, Planta, 197, 448455, 1995.

Marcolla, B., Pitacco, A., and Cescatti, A.: Canopy architecture and turbulence structure in a coniferous forest, Bound.-Layer Meteorol., 108, 39-59, 2003.

Mareckova, K., Wankmüller, R., Pinterits, M., and Moosman, L.: Inventory Review 2013. Stage 1 and 2 and review of gridded data, EMEP/CEIP Technical Report 1/2013, EEA/CEIP Vienna, 2013.

Marenco, A., Gouget, H., Nédélec, P., Pagés, J., and Karcher, F.: Evidence of a long-term increase in tropospheric ozone from Pic du Midi data series: Consequences: Positive radiative forcing, J. Geophys. Res.-Atmos., 99, 16617-16632, 1994.

Massman, W.: A review of the molecular diffusivities of $\mathrm{H}_{2} \mathrm{O}$, $\mathrm{CO}_{2}, \mathrm{CH}_{4}, \mathrm{CO}, \mathrm{O}_{3}^{-}, \mathrm{SO}_{2}, \mathrm{NH}_{3}, \mathrm{~N}_{2} \mathrm{O}, \mathrm{NO}, \mathrm{AND} \mathrm{NO}_{2}$ in air, $\mathrm{O}_{2}^{-}$AND N ${ }_{2}^{-}$near STP, Atmo. Environ., 32, 1111-1127, doi:10.1016/S1352-2310(97)00391-9, 1998.

McKay, M. D., Beckman, R. J., and Conover, W. J.: Comparison of three methods for selecting values of input variables in the analysis of output from a computer code, Technometrics, 21, 239-245, 1979.

Migliavacca, M., Meroni, M., Manca, G., Matteucci, G., Montagnani, L., Grassi, G., Zenone, T., Teobaldelli, M., Goded, I., Colombo, R., and Seufert, G.: Seasonal and interannual patterns of carbon and water fluxes of a poplar plantation under peculiar eco-climatic conditions, Agr. Forest Meteorol., 149, 1460-1476, 2009.

Mikkelsen, T. N., Ro-Poulsen, H., Hovmand, M. F., Jensen, N. O., Pilegaard, K., and Egeløv, A. H.: Five-year measurements of ozone fluxes to a Danish Norway spruce canopy, Atmos. Environ., 38, 2361-2371, 2004.

Mills, G., Hayes, F., Simpson, D., Emberson, L., Norris, D., Harmens, H., and Büker, P.: Evidence of widespread effects of ozone on crops and (semi-) natural vegetation in Europe (1990-2006) in relation to AOT40-and flux-based risk maps, Glob. Change Biol., 17, 592-613, 2011a.

Mills, G., Pleijel, H., Braun, S., Büker, P., Bermejo, V., Calvo, E., Danielsson, H., Emberson, L., Fernández, I., Grünhage, L., Harmens, H., Hayes, F., Karlsson, P., and Simpson, D.: New stomatal flux-based critical levels for ozone effects on vegetation, Atmos. Environ., 45, 5064-5068, $2011 \mathrm{~b}$.

Monteith, J. and Unsworth, M.: Principles of environmental physics, Academic Press, 2007.

Morgan, P., Ainsworth, E., and Long, S.: How does elevated ozone impact soybean? A meta-analysis of photosynthesis, growth and yield, Plant Cell Environ., 26, 1317-1328, 2003.

Musselman, R., Lefohn, A., Massman, W., and Heath, R.: A critical review and analysis of the use of exposure-and flux-based ozone indices for predicting vegetation effects, Atmos. Environ., 40, 1869-1888, 2006.

New, M., Hulme, M., and Jones, P.: Representing twentieth-century space-time climate variability, Part I: Development of a 19611990 mean monthly terrestrial climatology, J. Clim., 12, 829856, 1999.

Padro, J.: Summary of ozone dry deposition velocity measurements and model estimates over vineyard, cotton, grass and deciduous forest in summer, Atmos. Environ., 30, 2363-2369, 1996.

Paoletti, E. and Grulke, N.: Ozone exposure and stomatal sluggishness in different plant physiognomic classes, Environ. Pollut., 158, 2664-2671, 2010.

Parrish, D. D., Law, K. S., Staehelin, J., Derwent, R., Cooper, O. R., Tanimoto, H., Volz-Thomas, A., Gilge, S., Scheel, H.-E., Steinbacher, M., and Chan, E.: Long-term changes in lower tropospheric baseline ozone concentrations at northern mid-latitudes, Atmos. Chem. Phys., 12, 11485-11504, doi:10.5194/acp-1211485-2012, 2012.

Pereira, J. S., Mateus, J. A., Aires, L. M., Pita, G., Pio, C., David, J. S., Andrade, V., Banza, J., David, T. S., Paço, T. A., and Rodrigues, A.: Net ecosystem carbon exchange in three contrast- 
ing Mediterranean ecosystems - the effect of drought, Biogeosciences, 4, 791-802, doi:10.5194/bg-4-791-2007, 2007.

Pleijel, H., Danielsson, H., Emberson, L., Ashmore, M., and Mills, G.: Ozone risk assessment for agricultural crops in Europe: further development of stomatal flux and flux-response relationships for European wheat and potato, Atmos. Environ., 41, 30223040, 2007.

Rebmann, C., Anthoni, P., Falge, E., Göckede, M., Mangold, A., Subke, J.-A., Thomas, C., Wichura, B., Schulze, E.-D., Tenhunen, J., and Foken, T.: Carbon budget of a spruce forest ecosystem, Springer, 2004.

Reich, P.: Quantifying plant response to ozone: a unifying theory, Tree Physiol., 3, 63-91, 1987.

Reichstein, M., Falge, E., Baldocchi, D., Papale, D., Aubinet, M., Berbigier, P., Bernhofer, C., Buchmann, N., Gilmanov, T., Granier, A., Grünwald, T., Havránkovaá, K., Ilvesniemi, H., Janous, D., Knohl, A., Laurila, T., Lohila, A., Loustau, D., Matteucci, G., Meyers, T., Miglietta, F., Ourcival, J., Pumpanen, J., Rambal, S., Rotenberg, E., Sanz, M., Tenhunen, J., Seufert, G., Vaccari, F., Vesala, T., Yakir, D., and Valentini, R.: On the separation of net ecosystem exchange into assimilation and ecosystem respiration: review and improved algorithm, Glob. Change Biol., 11, 1424-1439, 2005.

Ren, W., Tian, H., Tao, B., Chappelka, A., Sun, G., Lu, C., Liu, M., Chen, G., and Xu, X.: Impacts of tropospheric ozone and climate change on net primary productivity and net carbon exchange of China's forest ecosystems, Glob. Ecol. Biogeogr., 20, 391-406, 2011.

Rey, A., Pegoraro, E., Tedeschi, V., De Parri, I., Jarvis, P. G., and Valentini, R.: Annual variation in soil respiration and its components in a coppice oak forest in Central Italy, Glob. Change Biol., 8, 851-866, 2002.

Richardson, A. D., Aubinet, M., Barr, A. G., Hollinger, D. Y., Ibrom, A., Lasslop, G., and Reichstein, M.: Uncertainty quantification, Springer, 2012.

Roeckner, E., Brokopf, R., Esch, M., Giorgetta, M., Hagemann, S., Kornblueh, L., Manzini, E., Schlese, U., and Schulzweida, U.: Sensitivity of simulated climate to horizontal and vertical resolution in the ECHAM5 atmosphere model, J. Clim., 19, 37713791, doi:10.1175/JCLI3824.1, 2006.

Samuelsson, P., Jones, C. G., Willen, U., Ullerstig, A., Gollvik, S., Hansson, U., Jansson, C., Kjellstrom, E., Nikulin, G., and Wyser, K.: The Rossby Centre Regional Climate model RCA3: model description and performance, Tellus A, 63, 4-23, doi:10.1111/j.1600-0870.2010.00478.x, 2011.

Sanz, M., Carrara, A., Gimeno, C., Bucher, A., and Lopez, R.: Effects of a dry and warm summer conditions on $\mathrm{CO}_{2}$ and Energy fluxes from three Mediterranean ecosystems, vol. 6, 2004.

Scherer-Lorenzen, M., Schulze, E.-D., Don, A., Schumacher, J., and Weller, E.: Exploring the functional significance of forest diversity: a new long-term experiment with temperate tree species (BIOTREE), Perspect. Plant Ecol., 9, 53-70, 2007.

Simpson, D., Winiwarter, W., Börjesson, G., Cinderby, S., Ferreiro, A., Guenther, A., Hewitt, C. N., Janson, R., Khalil, M. A. K., Owen, S., Pierce, T. E., Puxbaum, H., Shearer, M., Skiba, U., Steinbrecher, R., Tarrasón, L., and Öquist, M. G.: Inventorying emissions from Nature in Europe, J. Geophys. Res., 104, 8113$8152,1999$.
Simpson, D., Tuovinen, J.-P., Emberson, L., and Ashmore, M.: Characteristics of an ozone deposition module II: sensitivity analysis, Water Air Soil Pollut., 143, 123-137, 2003.

Simpson, D., Ashmore, M., Emberson, L., and Tuovinen, J.-P.: A comparison of two different approaches for mapping potential ozone damage to vegetation. A model study, Environ. Pollut., 146, 715-725, 2007.

Simpson, D., Benedictow, A., Berge, H., Bergström, R., Emberson, L. D., Fagerli, H., Flechard, C. R., Hayman, G. D., Gauss, M., Jonson, J. E., Jenkin, M. E., Nyíri, A., Richter, C., Semeena, V. S., Tsyro, S., Tuovinen, J.-P., Valdebenito, Á., and Wind, P.: The EMEP MSC-W chemical transport model - technical description, Atmos. Chem. Phys., 12, 7825-7865, doi:10.5194/acp-127825-2012, 2012.

Simpson, D., Arneth, A., Mills, G., Solberg, S., and Uddling, J.: Ozone - the persistent menace: interactions with the $\mathrm{N}$ cycle and climate change, Current Opinion in Environmental Sustainability, 9/10, 9-19, doi:10.1016/j.cosust.2014.07.008, 2014a.

Simpson, D., Christensen, J., Engardt, M., Geels, C., Nyiri, A., Soares, J., Sofiev, M., Wind, P., and Langner, J.: Impacts of climate and emission changes on nitrogen deposition in Europe: a multi-model study, Atmos. Chem. Physics, 14, 6995-7017, doi:10.5194/acp-14-6995-2014, 2014 b.

Sitch, S., Cox, P., Collins, W., and Huntingford, C.: Indirect radiative forcing of climate change through ozone effects on the landcarbon sink, Nature, 448, 791-794, 2007.

Sitch, S., Friedlingstein, P., Gruber, N., Jones, S. D., MurrayTortarolo, G., Ahlström, A., Doney, S. C., Graven, H., Heinze, C., Huntingford, C., Levis, S., Levy, P. E., Lomas, M., Poulter, B., Viovy, N., Zaehle, S., Zeng, N., Arneth, A., Bonan, G., Bopp, L., Canadell, J. G., Chevallier, F., Ciais, P., Ellis, R., Gloor, M., Peylin, P., Piao, S. L., Le Quéré, C., Smith, B., Zhu, Z., and Myneni, R.: Recent trends and drivers of regional sources and sinks of carbon dioxide, Biogeosciences, 12, 653679, doi:10.5194/bg-12-653-2015, 2015.

Staehelin, J., Thudium, J., Buehler, R., Volz-Thomas, A., and Graber, W.: Trends in surface ozone concentrations at Arosa (Switzerland), Atmos. Environ., 28, 75-87, 1994.

Stohl, A., Aamaas, B., Amann, M., Baker, L. H., Bellouin, N., Berntsen, T. K., Boucher, O., Cherian, R., Collins, W., Daskalakis, N., Dusinska, M., Eckhardt, S., Fuglestvedt, J. S., Harju, M., Heyes, C., Hodnebrog, Ø., Hao, J., Im, U., Kanakidou, M., Klimont, Z., Kupiainen, K., Law, K. S., Lund, M. T., Maas, R., MacIntosh, C. R., Myhre, G., Myriokefalitakis, S., Olivié, D., Quaas, J., Quennehen, B., Raut, J.-C., Rumbold, S. T., Samset, B. H., Schulz, M., Seland, Ø., Shine, K. P., Skeie, R. B., Wang, S., Yttri, K. E., and Zhu, T.: Evaluating the climate and air quality impacts of short-lived pollutants, Atmos. Chem. Phys., 15, 10529-10566, doi:10.5194/acp-15-10529-2015, 2015.

Suni, T., Rinne, J., Reissell, A., Altimir, N., Keronen, P., Rannik, U., Maso, M., Kulmala, M., and Vesala, T.: Long-term measurements of surface fluxes above a Scots pine forest in Hyytiala, southern Finland, 1996-2001, Boreal Environ. Res., 8, 287-302, 2003.

Tausz, M., Grulke, N., and Wieser, G.: Defense and avoidance of ozone under global change, Environ. Pollut., 147, 525-531, 2007.

Tedeschi, V., Rey, A., Manca, G., Valentini, R., Jarvis, P. G., and Borghetti, M.: Soil respiration in a Mediterranean oak forest 
at different developmental stages after coppicing, Glob. Change Biol., 12, 110-121, 2006.

Tirone, G., Dore, S., Matteucci, G., Greco, S., and Valentini, R.: Evergreen Mediterranean forests. carbon and water fluxes, balances, Ecological and ecophysiological determinants, Springer, 2003.

Tuovinen, J.-P., Simpson, D., Mikkelsen, T., Emberson, L., Ashmore, M., Aurela, M., Cambridge, H., Hovmand, M., Jensen, N., Laurila, T., Pilegaard, K., and Ro-Poulsen, H.: Comparisons of measured and modelled ozone deposition to forests in Northern Europe, Water Air Soil Pollut., 1, 263-274, 2001.

Tuovinen, J.-P., Ashmore, M., Emberson, L., and Simpson, D.: Testing and improving the EMEP ozone deposition module, Atmos. Environ., 38, 2373-2385, 2004.

Tuovinen, J.-P., Simpson, D., Emberson, L., Ashmore, M., and Gerosa, G.: Robustness of modelled ozone exposures and doses, Environ. Pollut., 146, 578-586, 2007.

Tuovinen, J.-P., Emberson, L., and Simpson, D.: Modelling ozone fluxes to forests for risk assessment: status and prospects, Ann. Forest Sci., 66, 1-14, 2009.

van Aardenne, J. A., Dentener, F. J., Olivier, J. G. J., Goldewijk, C. G. M. K., and Lelieveld, J.: A $1^{\circ} \times 1^{\circ}$ resolution data set of historical anthropogenic trace gas emissions for the period 1890-1990, Global Biogeochem. Cy., 15, 909-928, doi:10.1029/2000GB001265, 2001.

Vingarzan, R.: A review of surface ozone background levels and trends, Atmos. Environ., 38, 3431-3442, 2004.

Vitale, M., Gerosa, G., Ballarin-Denti, A., and Manes, F.: Ozone uptake by an evergreen mediterranean forest (Quercus ilex L.) in Italy - Part II: flux modelling. Upscaling leaf to canopy ozone uptake by a process-based model, Atmos. Environ., 39, 32673278, 2005.

Wieser, G. and Havranek, W.: Environmental control of ozone uptake in Larix decidua Mill.: a comparison between different altitudes, Tree Physiol., 15, 253-258, 1995.

Wieser, G. and Matyssek, R.: Linking ozone uptake and defense towards a mechanistic risk assessment for forest trees, New Phytol., 174, 7-9, 2007.

Wieser, G., Matyssek, R., Kostner, B., Oberhuber, W., and Kötner, B.: Quantifying ozone uptake at the canopy level of spruce, pine and larch trees at the alpine timberline: an approach based on sap flow measurement, Environ. Pollut., 126, 5-8, doi:10.1016/S0269-7491(03)00184-2, 2003.

Wilson, K., Goldstein, A., Falge, E., Aubinet, M., Baldocchi, D., Berbigier, P., Bernhofer, C., Ceulemans, R., Dolman, H., Field, C., Grelle, A., Ibrom, A., Law, B., Kowalski, A., Meyers, T., Moncrieff, J., Monson, R., Oechel, W., Tenhunen, J., Valentini, R., and Verma, S.: Energy balance closure at FLUXNET sites, Agr. Forest Meteorol., 113, 223-243, 2002.
Wittig, V., Ainsworth, E., and Long, S.: To what extent do current and projected increases in surface ozone affect photosynthesis and stomatal conductance of trees? A meta-analytic review of the last 3 decades of experiments, Plant Cell Environ., 30, 1150$1162,2007$.

Wittig, V., Ainsworth, E., Naidu, S., Karnosky, D., and Long, S.: Quantifying the impact of current and future tropospheric ozone on tree biomass, growth, physiology and biochemistry: a quantitative meta-analysis, Glob. Change Biol., 15, 396-424, 2009.

Wohlfahrt, G., Anderson-Dunn, M., Bahn, M., Balzarolo, M., Berninger, F., Campbell, C., Carrara, A., Cescatti, A., Christensen, T., Dore, S., Eugster, W., Friborg, T., Furger, M., Gianelle, D., Gimeno, C., Hargreaves, K., Hari, P., Haslwanter, A., Johansson, T., Marcolla, B., Milford, C., Nagy, Z., Nemitz, E., Rogiers, N., Sanz, M., Siegwolf, R., Susiluoto, S., Sutton, M., Tuba, Z., Ugolini, F., Valentini, R., Zorer, R., and Cernusca, A.: Biotic, abiotic, and management controls on the net ecosystem $\mathrm{CO}_{2}$ exchange of European mountain grassland ecosystems, Ecosystems, 11, 1338-1351, 2008a.

Wohlfahrt, G., Hammerle, A., Haslwanter, A., Bahn, M., Tappeiner, U., and Cernusca, A.: Seasonal and inter-annual variability of the net ecosystem $\mathrm{CO}_{2}$ exchange of a temperate mountain grassland: Effects of weather and management, J. Geophys. Res.-Atmos., 113, d08110, doi:10.1029/2007JD009286, 2008b.

Young, P. J., Archibald, A. T., Bowman, K. W., Lamarque, J.-F., Naik, V., Stevenson, D. S., Tilmes, S., Voulgarakis, A., Wild, O., Bergmann, D., Cameron-Smith, P., Cionni, I., Collins, W. J., Dalsøren, S. B., Doherty, R. M., Eyring, V., Faluvegi, G., Horowitz, L. W., Josse, B., Lee, Y. H., MacKenzie, I. A., Nagashima, T., Plummer, D. A., Righi, M., Rumbold, S. T., Skeie, R. B., Shindell, D. T., Strode, S. A., Sudo, K., Szopa, S., and Zeng, G.: Preindustrial to end 21st century projections of tropospheric ozone from the Atmospheric Chemistry and Climate Model Intercomparison Project (ACCMIP), Atmos. Chem. Physics, 13, 2063 2090, doi:10.5194/acp-13-2063-2013, 2013.

Zaehle, S. and Friend, A.: Carbon and nitrogen cycle dynamics in the O-CN land surface model: 1. Model description, site-scale evaluation, and sensitivity to parameter estimates, Global Biogeochem. Cy., 24, GB1005, doi:10.1029/2009GB003521, 2010.

Zhang, L., Brook, J. R., and Vet, R.: A revised parameterization for gaseous dry deposition in air-quality models, Atmos. Chem. Phys., 3, 2067-2082, doi:10.5194/acp-3-2067-2003, 2003.

Zaehle, S., Ciais, P., Friend, A. D., and Prieur, V.: Carbon benefits of anthropogenic reactive nitrogen offset by nitrous oxide emissions, Nat. Geosci., 4, 601-605, 2011. 